\title{
Enhanced Electrochemical Cu Release from Commercial Cu-Sn Alloys: Fate of the Alloying Elements in Artificial Perspiration
}

\author{
Authors: M. J. Hutchison ${ }^{\mathrm{a}}$, P. Zhou ${ }^{\mathrm{b}}$, K. Ogle ${ }^{\mathrm{b}}$, J.R. Scully ${ }^{\mathrm{a}}$ \\ ${ }^{a}$ Department of Materials Science and Engineering, University of Virginia, 395 McCormick Road, Charlottesville, VA 22904, USA \\ ${ }^{\mathrm{b}}$ Ecole Nationale Supérieure de Chimie de Paris, IRCP, CNRS, 11 Rue Pierre et Marie Curie, Paris 75005, France
}

\begin{abstract}
Commercially pure $\mathrm{Cu}(\mathrm{Cu}), \mathrm{Cu}-4.5 \mathrm{Sn}-0.1 \mathrm{Zn}$, and $\mathrm{Cu}-9.7 \mathrm{Sn}-0.1 \mathrm{Zn}(\mathrm{wt} \%)$ were evaluated for corrosion and cation release in modified artificial human perspiration solution. Open circuit corrosion exposures were conducted for up to 130 hours to determine corrosion rate and the fate of $\mathrm{Cu}$ and $\mathrm{Sn}$. Released aqueous ion concentrations were monitored via inductively-coupled plasma - optical emission spectroscopy (ICP-OES). Operando atomic emission spectroelectrochemistry (AESEC) analysis was utilized to elucidate the fate of $\mathrm{Cu}$, whether in oxides or solution and deduce the dominant valence states, $\mathrm{Cu}(\mathrm{I}) / \mathrm{Cu}$ (II), of soluble $\mathrm{Cu}$ in artificial perspiration. Sn was not observed as a soluble ionic species within ICP-OES or AESEC limits of detection (LOD). Corrosion products were characterized using grazing incidence X-ray diffraction (GIXRD), Raman spectroscopy, and X-ray photoelectron spectroscopy (XPS), and quantified with coulometric reduction (CR). $\mathrm{Cu}-4.5 \mathrm{Sn}-0.1 \mathrm{Zn}$ displayed the highest corrosion rates in artificial perspiration, followed by $\mathrm{Cu}-9.7 \mathrm{Sn}-0.1 \mathrm{Zn}$, and then $\mathrm{Cu}$. Primary corrosion products were $\mathrm{Cu}_{2} \mathrm{O}$, with $\mathrm{CuCl}$ as an outer solid product, and an inner layer of $\mathrm{SnO}_{2}$ for $\mathrm{Sn}$-containing alloys. $\mathrm{Cu}$ was dissolved as cuprous $\left(\mathrm{Cu}^{+}\right)$ ions. Minor $\mathrm{Sn}$ alloying in solid solution catalyzed $\mathrm{Cu}$ dissolution which is counteracted at higher $\mathrm{Sn}$ contents by a passivating layer of $\mathrm{SnO}_{2}$, achieving complete passivity at $10.3 \mathrm{wt} \% \mathrm{Sn}$ according to graph theory. Cu-9.7Sn-0.1Zn indicated semi-passive behavior, speculated to be due a $\mathrm{SnO}_{2}$ layer and close proximity $(9.7 \mathrm{wt} \%)$ to this critical value for passivation (10.3 wt\%). The effect of alloyed $\mathrm{Sn}$ as a dissolution promoter for electrochemical $\mathrm{Cu}$ ion release, critical Sn contents for passivity, and subsequent implications of antimicrobial function are discussed. Oxidized Zn was not detected above LOD nor demonstrated any measurable effect on corrosion in artificial perspiration.
\end{abstract}

Keywords: $\mathrm{Cu}-\mathrm{Sn}$ Bronze, $\mathrm{Cu}$ Release, Antimicrobial Copper, Copper Corrosion, Artificial Perspiration

(C) 2016. This manuscript version is made available under the Elsevier user license http://www.elsevier.com/open-access/userlicense/1.0/ 


\section{Introduction}

\subsection{Copper as Functional Antimicrobial Surface}

Copper has received renewed interest in corrosion and pathogenic microbiological communities due to recent works which demonstrate its ability to kill/inactivate even antibiotic-resistant so-called 'superbugs', such as methicillin-resistant Staphylococcus aureus (MRSA), via soluble $\mathrm{Cu}$ ion release [1-3]. Probable bacteria transmission sites such as high-touch surfaces containing perspiration droplets utilizing $\mathrm{Cu}$ alloys showed significantly reduced bacterial counts and nosocomial infections [4,5]. Despite this effect, $\mathrm{Cu}$ alloys remain undesirable for use in these high-touch applications due to tarnishing (surface discoloration from an oxide) from hand contact. Soluble ion release is required to maintain antimicrobial function and hence, metallic corrosion is compulsory. A critical balance is needed between corrosion and ion release: corrosion rates must be sufficient to release enough $\mathrm{Cu}$ for desired antimicrobial function with simultaneous adequate suppression of undesired tarnishforming and/or passivating oxides. Sufficiently thick or 'passive' oxides can also reduce bactericidal/fungicidal efficacy [6-8]. Alloy content-induced variations of oxide structure, porosity, and composition, while acknowledged, have not been addressed [6-8]. These variations play crucial roles as they can potentially completely deactivate antimicrobial action by suppressing copper release rates.

Stainless steel was revealed to be ineffective even with a bactericidal silver ion-containing coating [4]. An ideally-engineered $\mathrm{Cu}$-based alloy would tune passivation and copper ion release as regulated by major and minor alloying. Recently explored [9], the solid-solution $\mathrm{Cu}-\mathrm{Sn}$ system exhibited enhanced $\mathrm{Cu}$ release and concomitant increase in antimicrobial efficacy compared to $\mathrm{Cu}$ alone despite a lower bulk $\mathrm{Cu}$ content. This system is of particular interest to elucidate the mechanism by which such beneficial alloying elements function.

\subsection{Antimicrobial Copper Testing}

Generally, higher $\mathrm{Cu}$ content [8], temperature [2,3], and relative humidity [2,3] increase antimicrobial killing rates on copper surfaces. During so-called 'dry' tests (thin electrolyte films), copper can kill pathogenic bacteria within minutes [3]. Bronze $(\mathrm{Cu}-5 \mathrm{Sn})$ and pure copper had identical kill rates for multiple types of pathogenic bacteria: S. aureus, E. aerogenes, MRSA, P. aeruginosa, and E. coli [4]. Kill rate testing of MRSA indicated that pure copper and bronze $(\mathrm{Cu}-5 \mathrm{Sn})$ performed identically (>6 log reduction in $24 \mathrm{~h} \mathrm{[2])} \mathrm{despite} \mathrm{lower}$ bulk $\mathrm{Cu}$ content in the bronze. Critically, these studies do not provide a quantifiable dose-response relationship nor establish the mechanism which connects $\mathrm{Cu}$ alloy content with antimicrobial efficacy. 


\footnotetext{
${ }^{1}$ Bioavailable $\mathrm{Cu}$ and chelation effects $[1,8,12,13]$, are specifically related to the chemistry of the solution where corrosion trends of an alloy system should be grossly unaffected.
} situations despite acknowledging that corrosion is necessary for antimicrobial function. Bacteria growth media are merely physiological buffers that are not representative of simulative and more aggressive high-touch environments and may cause thicker oxides and/or higher corrosion rates. Indeed, environmental specificity potentially alters the observed trends with respect to copper alloying. Therefore, oxide formation and composition, ion valence state, corrosion response, electrolyte specificity, and solution complexing effects are critical to understanding antimicrobial function of $\mathrm{Cu}$-based alloys. Moreover, simulated human perspiration [11] contains known complexing and $\mathrm{Cu}$-chelating ${ }^{1}$ compounds [13] and offer a more representative electrolyte for high-touch environments.

\subsection{Corrosion and Ion Release of Copper Alloys in Simulated Human Perspiration Solution}

In a recent survey [9], several commercial copper-base alloys were investigated in artificial perspiration solution for corrosion response, soluble cation release, and oxide tarnish behavior. The results of this study established that $\mathrm{Cu}-\mathrm{Sn}$ alloys possessed enhanced $\mathrm{Cu}$ cation release relative to $\mathrm{Cu}$ despite having reduced $\mathrm{Cu}$ solvent content [9]. Furthermore, by simulating artificial perspiration as an analogue to a high-touch environment in both full immersion [14] and in wetting and drying cycles [15], prior passivation in air or furnace oxidation had a negligible effect on cation release for both pure copper and a tarnish-resistant $\mathrm{Cu}$ alloy (Cu-5Zn-5Al-1Sn). This result is likely due to the aggressiveness of the artificial perspiration solution and its $\mathrm{Cu}$-complexing effects [13]. $\mathrm{Cu}-\mathrm{Sn}$ bronze was also shown to have similar rainfall-induced runoff release as $\mathrm{Cu}$ despite having reduced bulk $\mathrm{Cu}$ content [16]. This would suggest that Sn alloying would be of interest for potential functional/tunable antimicrobial alloys. Yet, little is known about corrosion of $\mathrm{Cu}-\mathrm{Sn}$ alloys in perspiration solutions while atmospheric and fullimmersion studies on $\mathrm{Cu}$ alloys in marine environments are well-established $[17,18]$. Moreover, systematic effects of $\mathrm{Sn}$ alloying content on $\mathrm{Cu}-\mathrm{Sn}$ alloy dissolution or passivity remain unexplored. Given these findings, this study investigates the $\mathrm{Cu}-\mathrm{Sn}$ system for its unusual corrosion behavior and enhanced soluble $\mathrm{Cu}$ release. 


\subsection{Archeological Bronze Corrosion}

Bronze alloys exposed to atmospheric urban and industrial conditions (e.g., statues) usually exhibit protective power law oxide growth in the Wagner regime [19] and are often comprised of three layers: An inner layer of cuprite $\left(\mathrm{Cu}_{2} \mathrm{O}\right)$, an outer or middle layer of precipitated copper salts, and inner embedded tin oxide residues [19]. These patinas have high proportions of tin in the patina compared to their alloy content [20].

Sn enrichment in the corrosion product layer is a main characteristic of outdoor bronze corrosion [21]. Some copper remains in the patina, but most oxidized $\mathrm{Cu}$ is released in soluble form. Sn oxidation products in protective patinas are characterized as insoluble and amorphous or poorly-crystallized [21]. In vacuo Raman measurements suggested poorly or non-crystallized compounds with ambiguous attribution of cuprite and/or $\mathrm{Sn}$ (IV) oxide vibration modes that display similar characteristic peaks $\left(190-220 \mathrm{~cm}^{-1}\right.$, and $\left.620 \mathrm{~cm}^{-1}\right)$ [20]. Dendritic Cu13Sn (wt\%) demonstrated (in $\mathrm{Na}_{2} \mathrm{SO}_{4}, \mathrm{pH}$ 5.8) greater protective patinas covering dendrites of higher $\mathrm{Sn}$ content compared to the interdendritic regions (EDS determined $\mathrm{Sn} / \mathrm{Cu}: 0.30$ vs. 0.16 overall) [22]. Archeological studies of bronze provide critical insight into the factors governing the behavior of $\mathrm{Cu}-\mathrm{Sn}$ alloys. However, because of their forensic nature, these studies lack quantification of copper release rates or the fate of the elements.

\subsection{Rainfall-Induced Runoff of Cu: Bronze Alloys Undergoing Atmospheric Corrosion}

Bronze panels ( $\mathrm{Cu}-6 \mathrm{Sn})$ exposed to unsheltered atmospheric environments release comparable amounts of soluble $\mathrm{Cu}$ in rainfall-induced runoff ${ }^{2}$ compared to $\mathrm{Cu}$ sheets despite lower bulk $\mathrm{Cu}$ content $[16,23]$. Tin was not found in the form of soluble products when exposed in these conditions as evidenced by a lack of measurable tin content in captured rainwater runoff [16]. In marine atmospheric conditions bronze ( $\mathrm{Cu}-4 \mathrm{Sn})$ forms loosely adherent product films which were observed to flake and spall from the surface [24]. Sn was found in these studies to be retained at the inner oxide/alloy interface via EDS measurements. Atacamite $\left(\mathrm{Cu}_{2}(\mathrm{OH})_{3} \mathrm{Cl}\right)$ compounds were all found to be on the external oxide/fluid surface. The mechanism of flaking of bronze corrosion product is attributed to voluminous transformation of nantokite $(\mathrm{CuCl})$ to atacamite $\left(\mathrm{Cu}_{2}(\mathrm{OH})_{3} \mathrm{Cl}\right)$ [25]. Studies on the influence of

${ }^{2}$ Rainfall-induced runoff, measured by collecting the rainwater (artificial or outdoor atmospheric exposure), are related mostly to the chemical dissolution of the previously formed oxide in the outdoor environment, rather than electrochemical corrosion processes [12]. 


\section{Experimental Procedures}

\subsection{Materials}

Commercially pure $\mathrm{Cu}$ (99.9 wt\%, UNS C11000), Cu-4.5Sn-0.1Zn (UNS C51000), Cu-9.7Sn-0.1Zn (UNS C52480), and commercially pure Sn were evaluated. The wrought alloy sheets were obtained from commercial suppliers and sectioned into roughly $2.5 \mathrm{~cm} \times 2.5 \mathrm{~cm}$ pieces. Alloy compositions are given in Table 1 . The compositions of each commercial alloy were evaluated using ASTM E478 [26]. For comparison of alloy behavior without impurities (Zn or otherwise), a high-purity model binary alloy $\mathrm{Cu}-10 \mathrm{Sn}$ (wt $\%$ ) was fabricated via arc- 
melting. Alloy constituents were of $99.99 \%$ elemental purity by weight. Solid solution was facilitated by heat treatments and verified with X-ray diffraction (not shown). Selected data is presented in figures to highlight the effect of Sn, discussed later, rather than impurities and other minor alloying in the commercial Cu-Sn system. Simulated human perspiration solution (Table 2) was used as an appropriate analogue to a high-touch environment where copper alloys may be of interest. This solution is based on the BS EN 1811:2011 standard [11]. In addition, complexing and non-complexing buffers at the same $\mathrm{pH}$ (6.5) were prepared. Quantitative cation content in oxides (for AESEC) was facilitated by citrate buffer solutions (CBS), which were prepared from mixed $0.1 \mathrm{M}$ solutions of citric acid $\left(\mathrm{C}_{6} \mathrm{H}_{8} \mathrm{O}_{7}\right)$ and trisodium citrate $\left(\mathrm{Na}_{3} \mathrm{C}_{6} \mathrm{H}_{5} \mathrm{O}_{7}\right)$ solutions to achieve a $\mathrm{pH}$ of $5.00 \pm 0.1$. Non-complexing boric acid buffer at the same $\mathrm{pH}$ as artificial perspiration was prepared from mixing solutions of $0.1 \mathrm{M}$ boric acid $\left(\mathrm{H}_{3} \mathrm{BO}_{3}\right)$ and $0.1 \mathrm{M}$ sodium tetraborate $\left(\mathrm{Na}_{2} \mathrm{~B}_{4} \mathrm{O}_{7}\right)$, to achieve a target $\mathrm{pH}$ of $6.50 \pm 0.05$. A borate buffer ( $\mathrm{pH} 8.40$ $\pm 0.05)$ was prepared from $0.11 \mathrm{M}$ boric acid $\left(\mathrm{H}_{3} \mathrm{BO}_{3}\right)$ and $21 \mathrm{mM}$ sodium tetraborate $\left(\mathrm{Na}_{2} \mathrm{~B}_{4} \mathrm{O}_{7}\right)$ for coulometric reductions at a $\mathrm{pH}$ where existing $\mathrm{Cu}$ oxides are stable before reduction [27]. Buffer solutions of citric/citrate or boric/borate were deaerated for a minimum of one hour by grade-5 pure $\mathrm{N}_{2}$ gas bubbling prior to each test. Electrochemical cells were also purged with grade-5 nitrogen gas for at least $10 \mathrm{~min}$ prior to deaerated experiments with continuous bubbling throughout the duration of the test.

\subsection{Methods}

\subsection{Cyclic Voltammetry (CV)}

Cyclic voltammetry scans were conducted at sweep rates of $10 \mathrm{mV} / \mathrm{s}$ in deaerated boric acid buffer $(\mathrm{pH}$ 6.5) as well as borate buffer ( $\mathrm{pH} 8.4)$ from -1.145 to $+0.350 \mathrm{~V}_{\text {MMSE}}$. Prior to the first sweep, samples were polarized to ${ }^{-1.4} \mathrm{~V}_{\mathrm{MMSE}}$ for $10 \mathrm{~min}$ to reduce any air-formed oxide on the surface.

\subsection{On-line Operando AESEC Measurements}

A schematic description of this experimental methodology is given in Figure 1. Operando Atomic Emission Spectroelectrochemical (AESEC) measurements were conducted in a custom-designed 3-electrode 2compartment flow cell using a $\mathrm{Pt}$ counter $\left(5 \mathrm{~cm}^{2}\right)$ and $\mathrm{Ag} / \mathrm{AgCl}$ (sat. $\mathrm{KCl}$ ) reference electrode. The flow cell working electrode area was $A=1.0 \mathrm{~cm}^{2}$, and a flow rate $f=3.0 \mathrm{~mL} \mathrm{~min}^{-1}$ was used. Convolution calculations of the applied current compensating for the flow condition are provided in detail by the authors in a previous publication [28]. The details and capabilities of this technique are outlined elsewhere [29-32]. Briefly, an electrochemical flow cell's effluent stream is connected to an ICP-AES (Horiba Jobin Yvon, Ultima $2^{\mathrm{TM}}$ ). A Gamry Reference $600^{\mathrm{TM}}$ 
potentiostat was used to control applied current and monitor the potential. Simultaneous measurements of applied current and downstream ion concentration are obtained under open circuit and galvanostatic control. $\mathrm{Cu}, \mathrm{Cu}-4.5 \mathrm{Sn}$ $0.1 \mathrm{Zn}$, and $\mathrm{Cu}-9.7 \mathrm{Sn}-0.1 \mathrm{Zn}$ samples were subjected to $10 \mathrm{~min}$ of open circuit in synthetic perspiration solution, followed by a 20-min anodic pulse of $0,5,20$, or $80 \mu \mathrm{A} / \mathrm{cm}^{2}$ during which $\mathrm{Cu}$, and $\mathrm{Sn}$ ion release, and potential, were recorded. These time-frames and currents were selected to optimize the downstream signal for this experimental setup. After release of galvanostatic control, samples were allowed to stabilize for 10 min before switching the influent electrolyte to a deaerated CBS to chemically dissolve and therefore quantitatively assess corrosion product films. CBS was used due to its low corrosion rate of $\mathrm{Cu}$ and proven ability to chemically dissolve $\mathrm{Cu}$ oxides [28] without dissolving oxidized $\mathrm{Sn}$. Oxidation of Sn comprised only a small portion of total current. $\mathrm{Cu}$ signal was detected by monochromator at the wavelength of $324.75 \mathrm{~nm}$; $\mathrm{Sn}$ and $\mathrm{Zn}$ signals were detected by polychromator at $235.49 \mathrm{~nm}$ and $213.68 \mathrm{~nm}$, respectively. Cu ion calibration standards were 20, 40, and $60 \mathrm{ppb}$ in artificial perspiration solution and 20,40, and $100 \mathrm{ppb}$ in citrate buffer solution (CBS, pH $5.0 \pm 0.1$ ). The threestandard calibration was finished with correlation coefficient $R^{2} \geq 0.99$. The detection limit was defined as three times the standard deviation of the blank measured over $100 \mathrm{~s}$, with a $1 \mathrm{~s}$ integration time per point.

\subsection{Artificial Perspiration Exposure Conditions}

Alloy samples were polished with successive grades of abrasive SiC grit paper up to 1200 grit, during the final stage samples were polished under ethanol. Samples were then rinsed and stored in ethanol until placed into 3electrode electrochemical full-immersion exposure cells. Sample exposure area was $0.8 \mathrm{~cm}^{2}$. Cells were cleaned with $0.1 \mathrm{M} \mathrm{HCl}$ prior to each experiment and thoroughly rinsed with deionized water. For soluble ion concentration analysis: $300 \mathrm{ml}( \pm 2.5 \mathrm{~mL})$ of artificial perspiration were added to cells. Exposures were monitored and extracted where appropriate at specified time-points up to 130 hours. Electrochemical potentials in halide-containing solutions were measured using saturated calomel electrodes (SCE) fitted with Luggin capillary tips. Reproducibility of experiments was determined to be satisfactory as most experiments were replicated at least once and good agreement of trends was observed among multiple separate methodologies using independent samples. Corrosion rates were measured with mass loss and impedance circuit fits. The total anodic charge density from these results was then compared to the amount of corrosion products formed and soluble ions released, and all forms of metal cations were converted to charge density. Corrosion products were identified using grazing incidence X-ray diffraction (GIXRD), Raman spectroscopy, and X-ray photoelectron spectroscopy (XPS). 


\subsection{Corrosion Rate: Mass Loss and Electrochemical Impedance Spectroscopy (EIS)}

Mass loss measurements were conducted according to ASTM G1 [33]. Mass loss $\left(\mathrm{M}_{1}-\mathrm{M}_{3}\right)$ values were obtained by measuring mass of samples before $\left(\mathrm{M}_{1}\right)$ and after exposure $\left(\mathrm{M}_{2}\right)$ and again following a 2-3 min $6 \mathrm{M} \mathrm{HCl}$ cleaning step to remove both $\mathrm{Cu}, \mathrm{Zn}$, and $\mathrm{Sn}$ corrosion products $\left(\mathrm{M}_{3}\right)$. Base metal removal rates were determined to be negligible during cleaning as evaluated with a freshly polished sample. For charge analysis, congruent dissolution was assumed with equivalent weights of 63.6 g/equiv., 60.1 g/equiv., and 57.0 g/equiv. for $\mathrm{Cu}, \mathrm{Cu}-4.5 \mathrm{Sn}-0.1 \mathrm{Zn}$, and Cu-9.7Sn-0.1Zn, respectively.

Electrochemical impedance spectroscopy (EIS) measurements were performed on Gamry ${ }^{\circledR}$ Instruments REF600 potentiostats. Impedance was measured at 8 points per decade from $100 \mathrm{kHz}$ to $1 \mathrm{mHz}$. EIS analysis and model circuit fit was performed using ZView ${ }^{\circledR}$ and Gamry ${ }^{\circledR}$ software. An equivalent DC circuit (Figure 2) was simulated to determine the zero frequency (DC) limit of the impedance spectra which can then be related to the polarization resistance of the electrochemical system. Values were assigned to the circuit parameters which best fit the experimental data. A representative example fit of this circuit is given in Figure 2. Constant phase elements (CPE) were used in place of ideal capacitors in this circuit. The Warburg diffusional impedance $\left(\mathrm{Z}_{\mathrm{D}}\right)$ is defined as:

$$
Z_{D}=R_{D} \frac{\tanh \left(B_{D} \sqrt{j \omega}\right)}{B_{D} \sqrt{j \omega}}
$$

where $\mathrm{j}$ is the imaginary unit, $\omega$ is the angular frequency, and $\mathrm{R}_{\mathrm{D}}$ is the zero-frequency response of the Warburg element (under AC conditions) and is defined as follows:

$$
R_{D}=\frac{B_{D}}{Y_{D}}
$$

$Y_{D}$ is the admittance, and the definition of the parameter $B_{D}$ :

$$
B_{D}=\frac{\delta}{D^{1 / 2}}
$$

where $\delta$ is the Nernst boundary layer or rate-limiting product layer thickness and D is the average value of diffusion coefficients of the rate-determining diffusing species. The polarization resistance (Rp) defined for this system was as such:

$$
R_{P}=R_{o x}+R_{c t}+R_{D}
$$


$\mathrm{R}_{\mathrm{ox}}$ and $\mathrm{R}_{\mathrm{ct}}$ are the oxide resistance and charge transfer resistance of the system, respectively. The polarization resistance is inversely related to the instantaneous corrosion rate through a well-known Stern-Geary expression [34]. Based on inspection of potentiodynamic polarization data (not presented), an assumed Stern-Geary constant value of $\mathrm{B}=0.025 \mathrm{~V}$ was used for charge analysis which also provided a best fit for comparison with mass loss results. The total oxidation charge $\left(\mathrm{Q}_{\mathrm{EIS}}\right)$, as estimated from EIS, expressed as charge, was calculated:

$$
Q_{E I S}=\int \frac{B}{R_{P}} d t
$$

where dt is the time interval of interest. A total integration from all EIS-derived instantaneous corrosion rates was considered for the total anodic charge. An electrical equivalent circuit sensitivity study was performed to evaluate the relative influence of various circuit element values on the impedance response. Selected parameters were ranged independently while holding others constant surrounding a best fit as determined by fitting software.

\subsection{Solid Corrosion Products - Quantification}

Coulometric (galvanostatic) reductions (CR) were performed on Princeton Applied Research PAR273A potentiostats. Samples were removed from exposure cells and repositioned to chloride-free cells where constant current of $-20 \mu \mathrm{A}$ was applied to an exposed electrode area of $0.8 \mathrm{~cm}^{2}\left(-25 \mu \mathrm{A} / \mathrm{cm}^{2}\right)$. Reductions were performed in a deaerated chloride-free borate buffer $(\mathrm{pH}$ 8.4) with a mercury/mercurous sulfate reference electrodes also fitted with Luggin capillary tips. The amount of corrosion product expressed as charge $\left(\mathrm{Q}_{\mathrm{CR}}\right)$ was calculated from $\mathrm{CR}$ by the expression:

$$
Q_{C R}=i_{\text {app }} \times t_{\text {red }}
$$

where $i_{\text {app }}$ is the applied cathodic current density, and $t_{\text {red }}$ is the reduction time evaluated from firstderivative analysis. Reduction times of individual corrosion products were evaluated based intervals of the maxima of the first derivate (w.r.t. time) of the CR plots for each reduction wave.

\subsection{Solid Corrosion Products - Molecular Identity}

Crystalline products were identified using grazing incidence X-ray diffraction (GIXRD) using a PANalytical X'Pert diffractometer with copper $\mathrm{K} \alpha$ radiation. Incident grazing angle gave optimal signal/noise at $\omega=0.5^{\circ}$ with a $10 \mathrm{~mm}$ width limiting mask. $2 \Theta$ ranged from 20 to $100^{\circ}$. Compounds were identified by comparison to powder diffraction database (ICDD ${ }^{\circledR}$ PDF-4+). Detection limits of crystalline compounds for this instrument and methodology are approximately 5 vol\%. 
Raman spectroscopy measurements performed post-exposure were acquired using a Renishaw InVia Raman microscope, utilizing a $514 \mathrm{~nm}$ line of an argon laser with $180^{\circ}$ back scattering geometry and a $3000 \mathrm{l} / \mathrm{mm}$ grating. For compound identification, Raman spectra were compared with prepared in-house cold-pressed powder samples of known molecular identity and structure. To avoid thermal heating and conversion of sample corrosion products by laser illumination, low laser intensities with long ( minutes) acquisition times were used.

X-ray Photoelectron Spectroscopy (XPS) was also employed to investigate the corrosion products formed. A Thermo-Scientific K-Alpha ${ }^{\mathrm{TM}}$ XPS system was equipped with an $\mathrm{Al} \mathrm{K} \alpha$ monochromatic X-ray source and an Ar ion gun for sputtering. High-resolution scans were taken with a pass energy of $20 \mathrm{eV}$ and a spot size of $\sim 0.5 \mathrm{~mm}^{2}$. $\mathrm{Au} 4 \mathrm{f}_{7 / 2}$ was used as an energy reference assigned to $84.0 \mathrm{eV}$. Peak fits were made using a Shirley background and a Gaussian-Lorenzian shape. Spin orbit energy splits were set as the only constraint with all other parameters unconstrained for the best software fit.

\subsection{Release of $\mathrm{Cu}$ and $\mathrm{Sn}$ - Ions in solution}

A Thermo Scientific ${ }^{\mathrm{TM}}$ iCAP 6000 inductively-coupled plasma optical emission spectrometer (ICP-OES) was used for solution ion concentration determination. Aliquot samples taken from exposure cells at specified time points were stored and later directly nebulized into the plasma. Acidification was not performed on solution samples $^{3}$. Data points are averaged values of three measurements per aliquot with appropriate statistical variances applied to combine values of all measured wavelengths. Measured Cu lines were 2043, 2178, $2247 \AA$ A. Measured Sn lines: 1899 and $2243 \AA$ A. Limits of detection (LOD) were defined as the measured value of a blank sample of artificial perspiration (no $\mathrm{Cu}$ metal exposure) with three times the standard deviation added to this value. $\mathrm{Zn}$ was not measured as the maximum anticipated amount was below instrument limits ( $<1 \mathrm{ppb})$. LOD for $\mathrm{Cu}$ was $15 \mathrm{ppb}$, and $40 \mathrm{ppb}$ for Sn. Measured soluble $\mathrm{Cu}$ and $\mathrm{Sn}$ was also converted to charge ( $\left.\mathrm{Q}_{\mathrm{ICP}}\right)$, and evaluated as follows:

$$
Q_{I C P}=\sum \frac{\rho n F V}{A \cdot W}
$$

where rho is the measured $\mathrm{mg} / \mathrm{L}(\mathrm{ppm})$ value measured from photoemission intensity correlated to a calibration curve of serial-diluted prepared concentrations, $\mathrm{n}$ is the soluble ion valence. $\mathrm{F}$ is Faraday's constant (coul/equiv.), $\mathrm{V}$ is the solution cell volume (L), A.W. is atomic weight of the element (mg/equiv). Soluble ion

${ }^{3}$ Acidification did not produce any measureable differences in detected solution concentrations of $\mathrm{Cu}$. More information of ICP methodologies employed, including comments on acidification, can be found in [9]. 
concentration measured via ICP-OES were reported as charge using a Faradaic conversion with a $\mathrm{Cu}$ ion valence state assumed to be cuprous $\left(\mathrm{Cu}^{+}, \mathrm{n}=1\right)$. This assumption was validated by operando AESEC studies, the results of which are presented below.

\section{Results}

\subsection{Cyclic Voltammetry in Non-Complexing Buffer}

Cyclic voltammograms in deaerated boric acid buffers at $\mathrm{pH} 6.5$ and $\mathrm{pH} 8.4$ are shown in Figure 3. The first sweep (Figure 3a) and the third sweep (Figure 3b) are presented. This buffer is at the same pH as the artificial perspiration solution: $\mathrm{pH}=6.5$. An initial anodic peak was present on all alloys followed by an increasing current with increasing potentials indicating limited film induced mitigation. This E-I behavior was likely due to direct ion ejection during oxidation since all alloys demonstrate only one cathodic peak $\left(\mathrm{E}=-0.4 \mathrm{~V}_{\mathrm{SCE}}\right)$ attributed to cuprous reduction (Figure 3). $\mathrm{Cu}$-Sn alloys had greater anodic current densities compared to either $\mathrm{Cu}$ or $\mathrm{Sn}$. Anodic current densities were highest for $\mathrm{Cu}-4.5 \mathrm{Sn}-0.1 \mathrm{Zn}$ for all cycles when compared to the other alloys. In the first cycle (Figure 3a) the lowest current density for the anodic peak was found on $\mathrm{Cu}-9.7 \mathrm{Sn}-0.1 \mathrm{Zn}$. In the third cycle (Figure $3 \mathrm{~b}$ ) $\mathrm{Cu}-$ 9.7Sn-0.1Zn had higher current densities in the first anodic peak compared to $\mathrm{Cu}$. Commercial-purity $\mathrm{Sn}$ sheet showed initially high anodic activity in the first cycle (Figure 3a) but by the third, it became relatively insensitive to potential (Figure 3b), suggesting a passive film.

In contrast, at $\mathrm{pH} 8.4$ (Figure 3c) all alloys indicated clear oxidation and reduction of both $\mathrm{CuO}$ and $\mathrm{Cu}_{2} \mathrm{O}$ with substantial 'thick-film' passivation. $\mathrm{Cu}-4.5 \mathrm{Sn}-0.1 \mathrm{Zn}$ again exhibited the greatest anodic current densities at both $\mathrm{pH} 6.5$ and 8.4. $\mathrm{Cu}-9.7 \mathrm{Sn}-0.1 \mathrm{Zn}$ displayed lowered anodic reaction rates and a broad reduction peak. Cupric reduction was observed $\left(\mathrm{E}=-1.0 \mathrm{~V}_{\mathrm{SCE}}\right)$ at $\mathrm{pH} 8.4$ for all alloys (Figure 3c). The high purity $\mathrm{Cu}-10 \mathrm{Sn}$ alloy demonstrated nearly identical behavior to $\mathrm{Cu}-9.7 \mathrm{Sn}-0.1 \mathrm{Zn}$.

\subsection{Atomic Emission Spectroelectrochemistry - AESEC}

AESEC-measured downstream soluble $\mathrm{Cu}$ for all samples at an applied current of $80 \mu \mathrm{A} / \mathrm{cm}^{2}$ is presented in Figure 4a. AESEC results for all applied currents are shown for the Cu-9.7Sn-0.1Zn alloy in Figure 4b. Solid lines correspond to the measured mol/s of $\mathrm{Cu}$ while dashed lines are calculated ideal mol/s assuming 1:1 release (i.e. applied $\mathrm{e}^{-} \mathrm{mol} / \mathrm{s}=\mathrm{Cu} \mathrm{mol} / \mathrm{s}$ ) and accounting for the flow-cell condition [28]. This calculation accounts for the baseline open circuit corrosion rates which are determined from the control $\left(\mathrm{i}_{\text {app }}=0 \mu \mathrm{A} / \mathrm{cm}^{2}\right)$. Chemical dissolution 
in flowing deaerated CBS of mol/s of oxides pre-formed in perspiration were integrated over time to provide a quantitative measure of total $\mathrm{Cu}$ corrosion products and are indicated in mass balance calculations in Figure 5 .

Nearly all of the applied anodic current led directly to soluble $\mathrm{Cu}$ release. $\mathrm{Cu}$ and $\mathrm{Cu}-\mathrm{Sn}$ alloys indicated significant direct release of cuprous ions in comparison to corrosion product formation in artificial perspiration (Figure 4). Notably, $\mathrm{Cu}-9.7 \mathrm{Sn}-0.1 \mathrm{Zn}$ demonstrated the greatest release of $\mathrm{Cu}$ for the same applied currents than both $\mathrm{Cu}$ or $\mathrm{Cu}-4.5 \mathrm{Sn}-0.1 \mathrm{Zn}$ (Figure 4a). Greater moles of cuprite formed on $\mathrm{Cu}$ compared to $\mathrm{Cu}-4.5 \mathrm{Sn}-0.1 \mathrm{Zn}$ and $\mathrm{Cu}-$ 9.7Sn-0.1Zn (see Figure 5) for the same imposed current densities. Though, all samples displayed increased moles of corrosion product with applied current which was about 5-10\% of the total at all applied currents. As demonstrated in Figure 5, mass balance revealed that soluble cuprous ions $\left(\mathrm{Cu}^{+}\right)$and insoluble cuprous oxide $\left(\mathrm{Cu}_{2} \mathrm{O}\right)$ were the dominant forms of cations produced in artificial perspiration due to the close correlation between applied charge (e) converted to moles (mol/s) compared to total moles of measured ions (i.e. 1:1 correlation of applied moles of $\mathrm{e}^{-}$vs. sensed moles of $\mathrm{Cu}$, assuming $\mathrm{Cu}(\mathrm{I})$ oxidation). $\mathrm{SnO}_{2}$ is insoluble in both artificial perspiration CBS and thus was not detectable with AESEC.

Applied currents yielded corresponding anodic potentials which followed Tafel behavior with a slope of $\sim 76 \mathrm{mV} / \mathrm{dec}$ as shown in Figure 6. $\mathrm{Cu}$ required greater polarization compared to $\mathrm{Cu}-\mathrm{Sn}$ samples $(\Delta \mathrm{E} \sim 25 \mathrm{mV})$ at identical applied anodic currents suggesting that Sn promotes anodic dissolution.

\subsection{Interfacial Impedance and Corrosion Rate at Open Circuit}

Alloys with tin exhibited more noble open circuit potentials $(\sim+50 \mathrm{mV}$ after $48 \mathrm{~h})$ than $\mathrm{Cu}$ in artificial perspiration as conveyed in Figure 7. Cu decreased its open circuit potential after 24 hours in solution by $\sim 80 \mathrm{mV}$ while those alloys with tin retained higher OCPs which remained fairly constant after 12 hours of exposure. An identical elevation in potential was observed for the high-purity sample as well (Figure 7).

Visual appearance and secondary electron images of the outer surface of alloys after $130 \mathrm{~h}$ in artificial perspiration are presented in Figure 8. Uniform dark brown corrosion products were present for both commercially $\mathrm{Cu}$ (Figure 8a) and Cu-9.7Sn-0.1Zn (Figure 8c). Darker brown corrosion products were observed on $\mathrm{Cu}-4.5 \mathrm{Sn}-$ 0.1Zn (Figure 8b). Broken areas on product films were observed on $\mathrm{Cu}$ (Figure $8 \mathrm{a}$ ) as well as $\mathrm{Cu}-4.5 \mathrm{Sn}-0.1 \mathrm{Zn}$ (Figure 8b) with greater deterioration of surface layers compared to $\mathrm{Cu}-9.7 \mathrm{Sn}-0.1 \mathrm{Zn}$. Cu-9.7Sn-0.1Zn, did not demonstrate corrosion product film breakage which correlated with lower corrosion rates compared to $\mathrm{Cu}-4.5 \mathrm{Sn}$ 0.1Zn (Figure 11). All alloys displayed evenly distributed particles $(\sim 100 \mathrm{~nm})$ containing $\mathrm{Cu}$ and $\mathrm{Cl}$ (EDS, not 
shown) as shown in Figure 8c. Disruptions in the continuous layer (ascribed as $\mathrm{Cu}_{2} \mathrm{O}$ via EDS), were accompanied by greater $\mathrm{Cl}$-containing precipitates (Figure $8 \mathrm{a}$ and b), likely atacamite $\left(\mathrm{Cu}_{2}(\mathrm{OH})_{3} \mathrm{Cl}\right.$, or a structural polymorph) formed during sample drying. A cracked inner layer was observable in Figure $8 \mathrm{~b}$ and the edge of Figure 8c is rich in Sn and O (EDS not shown), which was ascribed to an inner layer of $\mathrm{SnO}_{2}$. This inner layer is strongly suggestive of mud-cracking of a hydrated compound upon drying following sample extraction and exposure to SEM chamber vacuum.

All impedance data showed evidence of at least two time constants with diffusional impedance behavior at lower frequencies (see Figure 9). An evaluation of the sensitivity of the equivalent circuit employed (Figure 10) demonstrates that a diffusion process was controlling near or approaching the zero-frequency-limit (under AC conditions) as those parameters (B, and $\left.\mathrm{Y}_{\text {diff }}\right)$ which relate to the Warburg diffusional impedance element (Eq. 1-3) entirely govern the sensitivity of the low frequency response and consequently, the corrosion rate (Eq. 4-5). The dominant mechanism is implied to be diffusion controlled. Figure 11 demonstrates that inverse polarization resistances obtained from impedance fits and using Eq. 4 showed two regimes. $\mathrm{Cu}$ and $\mathrm{Cu}-9.7 \mathrm{Sn}-0.1 \mathrm{Zn}$ showed an initial higher corrosion rate $\left(\mathrm{B} / \mathrm{R}_{\mathrm{p}}=\sim 4 \mu \mathrm{A} / \mathrm{cm}^{2}\right)$ followed by gradual decline over time to 1 and $2.5 \mu \mathrm{A} / \mathrm{cm}^{2}$, respectively. Cu-4.5Sn-0.1Zn exhibited higher corrosion rates $\left(9 \mu \mathrm{A} / \mathrm{cm}^{2}\right)$ than other alloys with gradual decline which stabilized after 48 hours $\left(\sim 4.5 \mu \mathrm{A} / \mathrm{cm}^{2}\right)$. All alloys' corrosion rates remained relatively constant after 48 hours (Figure 11). Cu-4.5Sn-0.1Zn showed the highest corrosion rate as measured by both mass loss and EIS circuit fits (Figure 11). In AESEC experiments, open circuit corrosion rates of $\mathrm{Cu}-4.5 \mathrm{Sn}-0.1 \mathrm{Zn}$ in perspiration were also higher than commercially pure copper (Figure $4 a)$.

\subsection{Corrosion Product Quantification after Open Circuit Exposure}

Coulometric reduction curves following exposure to artificial perspiration are shown in Figure 12. Several reduction waves were observed indicative of multiple corrosion products followed by a final plateau associated with electrolyte reduction (i.e., hydrogen evolution reaction - HER). The reduction times and plateau potentials for corrosion products' reductions on each alloy are shown in Figure 13. Reduction waves generally had increased reduction time with increasing exposure times. $\mathrm{Cu}$ (Figure 12a) in these time scales showed the greatest product thickness (i.e. greatest reduction charge) at 48 hours. Product thickness increased monotonically on Cu-Sn alloys as a function of increased exposure time (Figure $12 \mathrm{~b}$ and c). Cu- $4.5 \mathrm{Sn}-0.1 \mathrm{Zn}$ indicated relatively large $\left(2.2 \mathrm{Coul} / \mathrm{cm}^{2}\right.$ at $130 \mathrm{~h}$ ) total product thickness as a function of increasing exposure time. The anodic charge densities of individual 
corrosion products are given in Table 5. Assignments are justified in the next section. Considering analysis of the third wave $\left(\mathrm{E}_{\mathrm{red}}<-1.1 \mathrm{~V}_{\mathrm{MMSE}}\right.$, as $\mathrm{SnO}_{2}$ reduction), the $\mathrm{Sn}$ content in the product layer of $\mathrm{Cu}-4.5 \mathrm{Sn}-0.1 \mathrm{Zn}$ was negligible until 24 hours; after which Sn accounted for approximately $40 \%$ of the total charge of the product layer (Table 5). The greatest amounts of each corrosion product were found on $\mathrm{Cu}-4.5 \mathrm{Sn}-0.1 \mathrm{Zn}$. In contrast, $\mathrm{Cu}-9.7 \mathrm{Sn}-$ 0.1Zn displayed far less corrosion product formation after 130 hours $\left(0.4 \mathrm{Coul} / \mathrm{cm}^{2}\right)$ compared to $\mathrm{Cu}-4.5 \mathrm{Sn}-0.1 \mathrm{Zn}$ $\left(2.2 \mathrm{Coul} / \mathrm{cm}^{2}\right)$.

$\mathrm{Cu}-9.7 \mathrm{Sn}-0.1 \mathrm{Zn}$ exhibited parabolic growth of corrosion products $\left(\mathrm{Q}=0.0324 \cdot \mathrm{t}^{1 / 2}\right.$, Figure $\left.19 \mathrm{~d}\right)$. The first reduction wave $\left(\mathrm{E}_{\text {red }}>-0.8 \mathrm{~V}_{\mathrm{MMSE}}, \mathrm{CuCl}\right.$ ) was far less pronounced (Figure 12c) for $\mathrm{Cu}-9.7 \mathrm{Sn}-0.1 \mathrm{Zn}$. The relative amounts of Sn in all corrosion product layers remained fairly stable over time: the product charge was $\sim 60 \% \mathrm{Sn}$ (Table 5). It is worth noting that the higher ratio of $\mathrm{Sn}$ in the product layer correlated with the higher Sn content of the alloy. The total analysis of all reduction times $\left(\mathrm{t}_{\mathrm{red}}\right)$ indicated markedly less corrosion products on $\mathrm{Cu}-9.7 \mathrm{Sn}-$ $0.1 \mathrm{Zn}$.

\subsection{Corrosion Product Molecular Identity}

A summary of the compounds identified as solid corrosion products and methods used is given in Table 3 . A list of the measured photoelectron peaks and X-ray generated Auger peaks and their assignments based on literature-obtained values $[13,35-40]$ can be found in Table 4 . The three solid corrosion products identified herein were nantokite $(\mathrm{CuCl})$, cuprite $\left(\mathrm{Cu}_{2} \mathrm{O}\right)$, and oxidized $\mathrm{Sn}\left(\mathrm{SnO}_{\mathrm{x}}\right)$ assumed to be cassiterite $\left(\mathrm{SnO}_{2}\right)$. The identified corrosion products with their decreasing thermodynamic reduction potential order $\left(\mathrm{E}_{\text {red }}: \mathrm{CuCl}>\mathrm{Cu}_{2} \mathrm{O}>\mathrm{SnO}_{2}\right)$ were completely consistent with these three assignments when considering potential reduction plateaus in coulometric reduction (Figure 12).

\subsection{Nantokite $-\mathrm{CuCl}$}

Evidence of $\mathrm{CuCl}$ was indicated on $\mathrm{Cu}-4.5 \mathrm{Sn}-0.1 \mathrm{Zn}$ by one peak at $\left(2 \Theta=28.5^{\circ}, \mathrm{Cu} \mathrm{K}_{a}\right)$ utilizing GIXRD and is shown in Figure 14. This line is the most intense diffraction peak for nantokite [PDF: 00-006-0344, (111) plane]. XPS also revealed $\mathrm{Cl}$ (2p orbital) on the as-introduced surface and lightly sputtered $(\sim 20 \mathrm{~nm})$ surface (not shown). From this evidence the product is assumed to be nantokite $(\mathrm{CuCl})$. The potential plateau feature above -0.8 $\mathrm{V}_{\mathrm{MMSE}}$ (Figure 12) assumed to be $\mathrm{CuCl}$ was present on all alloys. However, this product may not have been strongly observable with GIXRD due to its small amount ( $<5$ vol\%). CuCl cannot be confirmed by Raman spectroscopy 
(Figure 15) as $\mathrm{CuCl}$ easily degrades through thermal heating even with low laser intensity approaching instrument noise levels [41].

\subsection{Cuprite - $\mathrm{Cu}_{2} \underline{\mathrm{O}}$}

The primary solid corrosion product for all three alloys was cuprous oxide $\left(\mathrm{Cu}_{2} \mathrm{O}\right)$. This product was observed with all techniques employed (Table 3). Raman spectroscopy (Figure 15) revealed only $\mathrm{Cu}_{2} \mathrm{O}$ the peak centered at $535 \mathrm{~cm}^{-1}$ is due to a $\mathrm{Cu}-\mathrm{OH}$ vibration in defective $\mathrm{Cu}_{2} \mathrm{O}$ [42] and therefore was not present in the prepared powder reference. GIXRD (Figure 14) verified cuprite formation for all alloys. Cuprite formation was greatest for $\mathrm{Cu}-4.5 \mathrm{Sn}-0.1 \mathrm{Zn}$ (Figure 13). X-Ray excited Auger Cu LMM transition photoelectric lines (Table 4) validated that oxidized $\mathrm{Cu}$ is in the cuprous state $[13,35-40]$, together with the absence of the characteristic cupric $2 p$ shift and shake-up satellite peaks in XPS which further confirmed the presence of cuprous oxide.

\section{8. $\underline{\text { Cassiterite }-\mathrm{SnO}_{2}}$}

Direct evidence of oxidized Sn was only observed using XPS (Figure 16) measured on a sample of Cu4.5Sn-0.1Zn corroded for 24 hours in artificial perspiration at open circuit. The sample was stored with desiccant during transport and tested within 24 hours of extraction to avoid conversion of corrosion products in ambient air (e.g., $\mathrm{CuCl} \rightarrow \mathrm{Cu}_{2}(\mathrm{OH})_{3} \mathrm{Cl}$ ). A pair of energy-shifted $3 \mathrm{~d}$ photoelectron peaks assigned to oxidized Sn was observable on the corroded sample and following sputtering $(\sim 250 \mathrm{~nm})$. Metallic Sn was also detected after sputtering indicating close proximity to the oxide/alloy interface. Signal intensity from oxidized tin greatly increased when near the oxide/alloy interface as illustrated in Figure 16. $\mathrm{SnCl}_{\mathrm{x}}$ species were excluded from consideration due to the lack of $\mathrm{Cl} 2 \mathrm{p}$ photoelectron peaks (198.4 eV, not shown) at the sputter depth near the oxide/alloy interface.

\subsection{Released Ions in Artificial Perspiration Solution}

Released $\mathrm{Cu}$ cations (Figure 17a) showed the greatest concentrations in solution at all exposure times from $\mathrm{Cu}-4.5 \mathrm{Sn}-0.1 \mathrm{Zn}$ followed by $\mathrm{Cu}-9.7 \mathrm{Sn}-0.1 \mathrm{Zn}$ and lastly $\mathrm{Cu}$. Sn was not observed above the LOD for any alloy (Figure 17b). Cation release from high purity $\mathrm{Cu}-10 \mathrm{Sn}$ is plotted alongside these results show comparable release to the $\mathrm{Cu}-9.7 \mathrm{Sn}-0.1 \mathrm{Zn}$ alloy as expected. Both $\mathrm{Cu}-\mathrm{Sn}$ alloys showed nearly constant rates of release while $\mathrm{Cu}$ indicated a decreased rate of cation release after 96 hours. Replicate sample exposures of $\mathrm{Cu}$ after 130 hours, given by open symbols (Figure 17a), demonstrate the reproducibility and data scatter of these measurements.

\subsection{Comparative Analysis of Total Charge}




\section{Discussion}

\subsection{Summary of Findings - Corrosion Behavior and Ion Release}

A schematic description of corrosion product morphology for each alloy and $\mathrm{Cu}$ is given in Figure 20. Corrosion product layers formed on $\mathrm{Cu}$ and $\mathrm{Cu}$-Sn alloys in artificial perspiration (Figure 20) in a manner consistent with the literature within $\mathrm{Cl}^{-}$containing environments [24,25]: an outer distribution of copper salts (e.g., $\mathrm{CuCl}$ ), a middle layer of defective cuprite $\left(\mathrm{Cu}_{2} \mathrm{O}\right)$, and an inner layer of hydrated cassiterite $\left(\mathrm{SnO}_{2}\right)$ for Sn-containing alloys. Retention of oxidized Sn at the alloy-corrosion product interface was also observed on corroded bronze evaluated via other methods such as cross-sectional metallography, glow discharge optical emission spectroscopy (GD-OES), XPS, EDS, and Raman mapping [24,25,36,38,40,42-44]. This layering was also evidenced by high-resolution XPS measurements taken at the sputter depth (Figure 16) near the corrosion product / $\mathrm{Cu}-\mathrm{Sn}$ alloy interface and furthermore supported by the literature in atmospheric, seawater, and archaeological studies $[21,24,25,36,38,40,44,45]$. 
Oxidized $\mathrm{Zn}$ was not detected with any measurement due to its low amount and furthermore was not observed to have any measurable influence on corrosion in this system. The two $\mathrm{Cu}$-Sn alloys also possess other minor elements (see Table 1) but were also not measureable with methods employed. It is reasonable to ascribe these effects to $\mathrm{Sn}$ rather than the minor elements as the high-purity $\mathrm{Cu}-10 \mathrm{Sn}$ sample demonstrates the same behavior as Cu-9.7Sn-0.1Zn in Figures 3c, 7, and 17a.

Notwithstanding the lack of a protective product layer (i.e. indicated by a decreasing rate of formation upon thickening), $\mathrm{Cu}$ had modest corrosion rates after $130 \mathrm{~h}$ in artificial perspiration ( $\mathrm{i}_{\text {corr }} \sim 1 \pm 1 \mu \mathrm{A} / \mathrm{cm}^{2}$ ). The corrosion rate and $\mathrm{OCP}$ of $\mathrm{Cu}-4.5 \mathrm{Sn}-0.1 \mathrm{Zn}$ were highest among the alloys tested $\left(\mathrm{i}_{\text {corr }}=5 \pm 1 \mu \mathrm{A} / \mathrm{cm}^{2}, \mathrm{E}_{\mathrm{OCP}}=-30 \mathrm{mV}_{\mathrm{SCE}}\right.$ ), also without protective corrosion products for all investigated times (Figure 19). $\mathrm{Cu}-4.5 \mathrm{Sn}-0.1 \mathrm{Zn}$ had greater anodic current density for a given potential as revealed by both cyclic voltammetry and AESEC (Figures 3 and 6, respectively). The greatest release of ionic $\mathrm{Cu}$ in solution $\left(1.2 \mathrm{mg} / \mathrm{cm}^{2}\right.$ after $\left.130 \mathrm{~h}\right)$ was observed on this alloy $(\mathrm{Cu}-$ 4.5 $\mathrm{Sn}-0.1 \mathrm{Zn}$ ), interpreted to be commensurate with its elevated corrosion rate. $\mathrm{Cu}-4.5 \mathrm{Sn}-0.1 \mathrm{Zn}$ had the greatest anodic current density as a function of applied potentials compared to $\mathrm{Cu}-9.7 \mathrm{Sn}-0.1 \mathrm{Zn}$ and $\mathrm{Cu}(\mathrm{CV}$, Figure 3). AESEC galvanostatic tests mirrored this result, as lower potentials were observed on $\mathrm{Cu}-4.5 \mathrm{Sn}-0.1 \mathrm{Zn}$ as a function of applied current density when compared to $\mathrm{Cu}$ (Figure 6) demonstrating that $\mathrm{Cu}-\mathrm{Sn}$ is more anodically active than $\mathrm{Cu}$. Diminution of this effect on $\mathrm{Cu}-9.7 \mathrm{Sn}-0.1 \mathrm{Zn}$ can be ascribed to its protective corrosion product formation. Based on the more positive potential observed and higher Sn content, the corrosion rate of $\mathrm{Cu}-9.7 \mathrm{Sn}-0.1 \mathrm{Zn}$ would be anticipated to be as high as or worse than $\mathrm{Cu}-4.5 \mathrm{Sn}-0.1 \mathrm{Zn}$. However, the corrosion rate of $\mathrm{Cu}-9.7 \mathrm{Sn}-0.1 \mathrm{Zn}$ was significantly lower than $\mathrm{Cu}-4.5 \mathrm{Sn}-0.1 \mathrm{Zn}\left(2.5\right.$ vs $4.5 \mu \mathrm{A} / \mathrm{cm}^{2}$ at 130 hours, respectively, see Figure 11$)$. Corrosion product production on this alloy (Cu-9.7Sn-0.1Zn) was lowest among all alloys (Figure 19d) and a pseudo-passive or protective product layer formation behavior substantiated by parabolic growth of corrosion products was observed with EIS, mass loss (Figure 11), and CR (Figure 12). Yet, $\mathrm{Cu}$ ion release (Figure 17) from Cu-9.7Sn-0.1Zn was nearly identical to $\mathrm{Cu}-4.5 \mathrm{Sn}-0.1 \mathrm{Zn}$ despite lower bulk $\mathrm{Cu}$, protective corrosion product growth (Figure $19 \mathrm{~d}$ ), and reduced corrosion rates (Figure 19a, and b). This suggests a high residual rate of direct $\mathrm{Cu}$ cation ejection through semi-protective $\mathrm{SnO}_{2}$ layer. From these observations, one can infer that $\mathrm{Cu}-9.7 \mathrm{Sn}-0.1 \mathrm{Zn}$ forms a corrosion product layer which is more uniform with fewer disruptions in coverage in solution. Predictably, $\mathrm{Cu}-9.7 \mathrm{Sn}-0.1 \mathrm{Zn}$ corrosion products as observed under SEM (Figure 8c) were more uniform than the corrosion products on other alloys (Figure 8a and b). CV results (Figure 3) corroborate this assumption. For this alloy (Cu-9.7Sn-0.1Zn), overall 


\subsection{Rate Limiting Step and Corrosion Mechanisms}

From the impedance data, referring to Equation 3, and taking the effective diffusion distance $\delta$ as the corrosion product layer estimated from multiple methods, effective diffusion coefficient values calculated for all samples $(0 \rightarrow 10 \mathrm{wt} \% \mathrm{Sn})$ and times $(0 \rightarrow 130$ hours $)$ range from $10^{-10} \leftrightarrow 10^{-17} \mathrm{~cm}^{2} / \mathrm{s}$. This result would imply that $\mathrm{Cu}$ cation diffusion outward from the surface (through $\mathrm{SnO}_{2} / \mathrm{Cu}_{2} \mathrm{O}$ ) is controlling as is consistent with other bronze corrosion findings [20-22]. Typically, the diffusion coefficient of oxygen in aqueous solution is on the order of $10^{-5}$ $\mathrm{cm}^{2} / \mathrm{s}$ [47], far too fast to be the rate-controlling factor in this case.

$\mathrm{Cu}$ was simultaneously released as both cuprite $\left(\mathrm{Cu}_{2} \mathrm{O}\right)$ and soluble cuprous ions in artificial perspiration for both $\mathrm{Cu}$ and $\mathrm{Cu}-\mathrm{Sn}$ alloys as determined from AESEC testing (Figure 5) and confirmed with cyclic voltammetry (Figure 3) in non-complexing buffer of the same $\mathrm{pH}(6.5) . \mathrm{Cu}$ and $\mathrm{Cu}-\mathrm{Sn}$ alloys favored cuprous ion release over corrosion product formation in artificial perspiration (Figure 5). Kinetic information of copper corrosion probed by AESEC in a previous publication [28] also proposed a simultaneous mechanism of both ion release and oxide formation. Modifications here include cuprous ion release, reflective of the solution chemistry employed and the role of Sn [28]. Cuprous ion release from the alloy occurs directly from the metal and is increased by Sn in solid solution:

$$
\mathrm{Cu}[\mathrm{Sn}] \rightarrow \mathrm{Cu}^{+}(a q)+e^{-}
$$

Simultaneously, cuprous oxide (cuprite) formation occurs also directly from the metallic state:

$$
2 \mathrm{Cu}[\mathrm{Sn}]+\mathrm{H}_{2} \mathrm{O} \rightarrow \mathrm{Cu}_{2} \mathrm{O}+2 e^{-}+2 \mathrm{H}^{+}
$$

Typically, $\mathrm{CuCl}$ is reported to form from a precipitation reaction: 


$$
\mathrm{Cu}_{2} \mathrm{O}+2 \mathrm{Cl}^{-}+2 \mathrm{H}^{+} \rightarrow 2 \mathrm{CuCl}+\mathrm{H}_{2} \mathrm{O}
$$

Alternatively, $\mathrm{CuCl}$ can be chemically formed from cuprite:

Were $\mathrm{CuCl}$ formed via Eq. 10, the soluble ion concentration of the reacting species, $\left[\mathrm{Cu}^{+}\right]$and $\left[\mathrm{Cl}^{-}\right]$, would dictate the nantokite $(\mathrm{CuCl})$ product yield and therefore would be identical for $\mathrm{Cu}-4.5 \mathrm{Sn}-0.1 \mathrm{Zn}$ and $\mathrm{Cu}-9.7 \mathrm{Sn}-0.1 \mathrm{Zn}$. However, $\mathrm{CuCl}$ formed via Eq. 11 would result in the greatest amounts of $\mathrm{CuCl}$ would increase with corrosion rate which was observed here (Cu-4.5Sn-0.1Zn, Table 5).

In both full immersion exposures and AESEC experiments, soluble Sn was not detected (Figure 17b) nor chemically and only slightly dissolved by CBS. Regardless, based on CR (Figure 12d), CV (Figure 3a), SEM (Figure 8), XPS (Figure 16), and a lower free energy of formation, Sn is likely oxidized first $[22,45]$ and forms a hydrated $\mathrm{SnO}_{2}$ layer at the metal /corrosion product interface:

$$
\mathrm{Sn}+2 \mathrm{H}_{2} \mathrm{O} \rightarrow \mathrm{SnO}_{2}+4 \mathrm{H}^{+}+4 e^{-}
$$

$\mathrm{CV}$ and CR results on pure Sn sheet (Figures 3 and 12d) demonstrate that a thin oxidized layer of Sn was readily formed initially at low potentials $\left(\mathrm{E}=-0.6 \mathrm{~V}_{\mathrm{SCE}}\right)$ which then exhibits a low anodic dissolution rate at the $\mathrm{pH}$ (6.5) and potential ranges $\left(-0.8 \mathrm{~V}_{\mathrm{SCE}}<\mathrm{E}<+0.8 \mathrm{~V}_{\mathrm{SCE}}\right)$ consistent with open circuit corrosion of Cu-Sn alloys in artificial perspiration (Figure 7).

\subsection{Effect of Sn: Enhanced Dissolution and Passivity}

Two main observations as to the effect of $\mathrm{Sn}$ as a solute in $\mathrm{FCC} \mathrm{Cu}$ were observed: an elevated open circuit potential typical of films obeying Wagner growth (Figure 7), and an enhanced dissolution fraction of Cu released which increases with Sn content rather than $\mathrm{Cu}$ content (Figures 17-19). Evaluation of the impedance results (Figure 10) and prior literature [20-22] suggest that outward cation diffusion through $\mathrm{Cu}_{2} \mathrm{O} / \mathrm{SnO}_{2}$ controls the corrosion rate. Moreover, increased open circuit potentials on $\mathrm{Cu}-\mathrm{Sn}$ is due to Wagner-regime oxide films formed on the surface. We speculate that anodic dissolution kinetics of alloys are governed by their chemical composition, reflected in atomic bonding [48]. The enhanced $\mathrm{Cu}$ release on $\mathrm{Cu}-\mathrm{Sn}$ may be understood by considering atomic bonding of $\mathrm{Cu}$ and $\mathrm{Sn}$ in solid solution. Sn nearest neighbors in $\mathrm{Cu}$ functions as a dissolution promoter due to the weaker $\mathrm{Cu}-\mathrm{Sn}$ bond $\left(\Delta \mathrm{H}_{\mathrm{f}, 298}=177 \mathrm{~kJ} / \mathrm{mol}\right.$ [49]), compared to $\mathrm{Cu}-\mathrm{Cu}(202 \mathrm{~kJ} / \mathrm{mol}$ [49]); this has an effect even in small solute concentrations of a few atomic percent as solute $(\mathrm{Sn})$ affects its surrounding $\mathrm{Cu}$ neighbors. Yet, Sn remains on the surface due to both its insolubility in this electrolyte (Figure 17b) and strong affinity for oxide formation $\left(\mathrm{SnO}_{2}\right.$ : 
$\left.\Delta \mathrm{G}_{\mathrm{f}, 298}=-519 \mathrm{~kJ} / \mathrm{mol}[21]\right) . \mathrm{Cu}$ atoms surrounding the $\mathrm{Sn}$ solute consequently have increased anodic activity resulting in greater dissolution rates. Indeed, solute elements such as $\mathrm{Cr}$ are also dissolution promoters in $\mathrm{Fe}$ solvents (stainless steels) $[48,50]$, though the stable passive $\mathrm{Cr}_{2} \mathrm{O}_{3}$ film typically conceals this effect at higher $\mathrm{Cr}$ alloying contents (e.g., 13 wt\% Cr). Sn-enhanced cuprous ion release was observed for both $\mathrm{Cu}-\mathrm{Sn}$ alloys, but was functionally different for the two alloys. $\mathrm{Cu}-4.5 \mathrm{Sn}-0.1 \mathrm{Zn}$ released $\mathrm{Cu}$ preferentially, but this was accompanied by a higher overall corrosion rate. The tin composition of $\mathrm{Cu}-9.7 \mathrm{Sn}-0.1 \mathrm{Zn}$ was close to the critical $\mathrm{Sn}$ content for passivity (10.3 Sn [46]) calculated from graph theory, which yielded semi-passive behavior. This $\mathrm{SnO}_{2}$ film limits the overall corrosion rate yet maintained enhanced $\mathrm{Cu}$ release originating from the dissolution promoter effect of metallic $\mathrm{Sn}$ as a solute in FCC Cu.

\section{Conclusions}

- $\mathrm{Cu}-\mathrm{Sn}$ in artificial perspiration provided a continuous supply of soluble cuprous ions into the environment (and available for antimicrobial function) linearly with respect to exposure time up to 130 hours whereas $\mathrm{Cu}$ ion release from $\mathrm{Cu}$ plateaued approaching 96 hours of exposure.

- In solid solution FCC Cu, $\mathrm{Sn}$ was observed to enhanced $\mathrm{Cu}$ release in artificial perspiration from $\mathrm{Cu}-\mathrm{Sn}$ alloys whereas oxidized $\mathrm{Sn}$ was retained on the surface as $\mathrm{SnO}_{2}$ due to oxide insolubility.

- The enhanced soluble $\mathrm{Cu}$ release of $\mathrm{Cu}-4.5 \mathrm{Sn}-0.1 \mathrm{Zn}$ was due to an elevated corrosion rate with incomplete $\mathrm{SnO}_{2}$ coverage.

- Alloying $\mathrm{Cu}$ with $10 \mathrm{wt} \% \mathrm{Sn}(\mathrm{Cu}-9.7 \mathrm{Sn}-0.1 \mathrm{Zn})$ also demonstrated enhanced ionic Cu release offset by lower corrosion rates due to a more complete protective inner $\mathrm{SnO}_{2}$ layer coverage in artificial perspiration.

\section{Acknowledgements}

This project was funded by the National Science Foundation (DMR-1309999) with Program Director Dr. Diana Farkas. XPS measurements were conducted at the US Naval Research Laboratory with assistance from Dr. Derek Horton and Dr. Donald Roeper. Their help and knowledge are deeply appreciated. Michael Holleman is acknowledged for laboratory assistance. Members of the Center for Electrochemical Science and Engineering (CESE) are thanked for various assistance and helpful discussions. 


\section{References}

[1] G. Grass, C. Rensing, M. Solioz, Metallic Copper as an Antimicrobial Surface, Appl. Environ. Microbiol. 77 (2011) 1541-1547. doi:10.1128/aem.02766-10.

[2] H.T. Michels, J.O. Noyce, C.W. Keevil, Effects of temperature and humidity on the efficacy of methicillinresistant Staphylococcus aureus challenged antimicrobial materials containing silver and copper, Lett. Appl. Microbiol. 49 (2009) 191-195. doi:10.1111/j.1472-765X.2009.02637.x.

[3] J.O. Noyce, H. Michels, C.W. Keevil, Potential use of copper surfaces to reduce survival of epidemic meticillin-resistant Staphylococcus aureus in the healthcare environment, J. Hosp. Infect. 63 (2006) $289-297$. doi:10.1016/j.jhin.2005.12.008.

[4] H.T. Michels, W. Moran, J. Michel, Antimicrobial Properties of Copper Alloy Surfaces, with a Focus on Hospital-Acquired Infections, Int. J. Met. (2008) 47-56.

[5] A.L. Casey, D. Adams, T.J. Karpanen, P.A. Lambert, B.D. Cookson, P. Nightingale, L. Miruszenko, R. Shillam, P. Christian, T.S.J. Elliott, Role of copper in reducing hospital environment contamination, J. Hosp. Infect. 74 (2010) 72-77. doi:10.1016/j.jhin.2009.08.018.

[6] D. Quaranta, T. Krans, C.E. Santo, C.G. Elowsky, D.W. Domaille, C.J. Chang, G. Grass, Mechanisms of Contact-Mediated Killing of Yeast Cells on Dry Metallic Copper Surfaces, Appl. Environ. Microbiol. 77 (2011) 416-426. doi:10.1128/aem.01704-10.

[7] C.E. Santo, E.W. Lam, C.G. Elowsky, D. Quaranta, D.W. Domaille, C.J. Chang, G. Grass, Bacterial Killing by Dry Metallic Copper Surfaces, Appl Env. Microbiol. 77 (2011) 794-802. doi:10.1128/aem.01599-10.

[8] L. Weaver, H.T. Michels, C.W. Keevil, Survival of Clostridium difficile on copper and steel: futuristic options for hospital hygiene, J. Hosp. Infect. 68 (2008) 145-151. doi:10.1016/j.jhin.2007.11.011.

[9] D.J. Horton, H. Ha, L.L. Foster, H.J. Bindig, J.R. Scully, Tarnishing and Cu Ion release in Selected CopperBase Alloys: Implications towards Antimicrobial Functionality, Electrochimica Acta. 169 (2015) 351-366. doi:10.1016/j.electacta.2015.04.001.

[10] Y.-S.E. Lin, R.D. Vidic, J.E. Stout, V.L. Yu, Individual and combined effects of copper and silver ions on inactivation of Legionella pneumophila, Water Res. 30 (1996) 1905-1913. doi:10.1016/0043-1354(96)000772.

[11] B.E. 1811, Reference test method for release of nickel from all post assemblies which are inserted into pierced parts of the human body and articles intended to come into direct and prolonged contact with the skin, (2011).

[12] J. Sandberg, I.O. Wallinder, C. Leygraf, N. Le Bozec, Corrosion-induced copper runoff from naturally and pre-patinated copper in a marine environment, Corros. Sci. $48 \quad$ (2006) 4316-4338. doi:10.1016/j.corsci.2006.04.004.

[13] I. Milošev, T. Kosec, Metal ion release and surface composition of the $\mathrm{Cu}-18 \mathrm{Ni}-20 \mathrm{Zn}$ nickel-silver during 30 days immersion in artificial sweat, Appl. Surf. Sci. 254 (2007) 644-652. doi:10.1016/j.apsusc.2007.06.049.

[14] L.L. Foster, M. Hutchison, J.R. Scully, The Fate of Copper During Corrosion of Cu-5Zn-5Al-1Sn (89\% Cu, $5 \% \mathrm{Zn}, 5 \% \mathrm{Al}, 1 \% \mathrm{Sn}$ ) Compared to Copper in Synthetic Perspiration Solution, Corrosion. 72 (2016) 51-65. doi: $10.5006 / 1885$.

[15] L.L. Foster, J.R. Scully, Corrosion of Cu-5Zn-5Al-1Sn (89\% Cu, 5\% Zn, 5\% Al, 1\% Sn) Compared to Copper in Synthetic Perspiration During Cyclic Wetting and Drying: The Fate of Copper, Corrosion. 72 (2016) 10951106. doi:10.5006/2063.

[16] S. Goidanich, I. Odnevall Wallinder, G. Herting, C. Leygraf, Corrosion induced metal release from copper based alloys compared to their pure elements, Corros. Eng. Sci. Technol. 43 (2008) $134-141$. doi:10.1179/174327808x286383.

[17] A.S.M.I.H.C. ASM Handbook Committee, Metals handbook, American Society for Metals, Metals Park, Ohio, 1978.

[18] M. Schumacher, Seawater corrosion handbook, http://books.google.com/books?id=HNRRAAAAMAAJ.

[19] C. Leygraf, T. Graedel, Atmospheric Corrosion, John Wiley \& Sons, INC., 2000.

[20] L. Robbiola, K. Rahmouni, C. Chiavari, C. Martini, D. Prandstraller, A. Texier, H. Takenouti, P. Vermaut, New insight into the nature and properties of pale green surfaces of outdoor bronze monuments, Appl. Phys. A. 92 (2008) 161-169. doi:10.1007/s00339-008-4468-4.

[21] L. Robbiola, J.M. Blengino, C. Fiaud, Morphology and mechanisms of formation of natural patinas on archaeological Cu-Sn alloys, Corros. Sci. 40 (1998) 2083-2111. doi:10.1016/S0010-938X(98)00096-1.

[22] I. Mabille, A. Bertrand, E.M.M. Sutter, C. Fiaud, Mechanism of dissolution of a $\mathrm{Cu}-13 \mathrm{Sn}$ alloy in low aggressive conditions, Corros. Sci. 45 (2003) 855-866. doi:10.1016/S0010-938X(02)00207-X. 
[23] G. Herting, S. Goidanich, I.O. Wallinder, C. Leygraf, Corrosion-induced release of Cu and $\mathrm{Zn}$ into rainwater from brass, bronze and their pure metals. A 2-year field study, Environ. Monit. Assess. 144 (2008) 455-461. doi:10.1007/s10661-007-0008-5.

[24] X. Zhang, I. Odnevall Wallinder, C. Leygraf, Mechanistic studies of corrosion product flaking on copper and copper-based alloys in marine environments, Corros. Sci. 85 (2014) 15-25. doi:10.1016/j.corsci.2014.03.028.

[25] I. Wallinder Odnevall, X. Zhang, S. Goidanich, N. Le Bozec, G. Herting, C. Leygraf, Corrosion and runoff rates of $\mathrm{Cu}$ and three $\mathrm{Cu}$-alloys in marine environments with increasing chloride deposition rate, Sci. Total Environ. 472 (2014) 681-694. doi:10.1016/j.scitotenv.2013.11.080.

[26] ASTM, Standard Test Methods for Chemical Analysis of Copper Alloys, ASTM International, West Conshohocken, PA, 2005. www.astm.org.

[27] P. Marcel, Atlas of Electrochemical Equilibria in Aqueous Solutions, Second English Edition, National Association of Corrosion Engineers, Houston, TX, 1974.

[28] P. Zhou, M.J. Hutchison, J.R. Scully, K. Ogle, The anodic dissolution of copper alloys: Pure copper in synthetic tap water, Electrochimica Acta. 191 (2016) 548-557. doi:10.1016/j.electacta.2016.01.093.

[29] K. Ogle, J. Baeyens, J. Swiatowska, P. Volovitch, Atomic emission spectroelectrochemistry applied to dealloying phenomena: I. The formation and dissolution of residual copper films on stainless steel, Electrochimica Acta. 54 (2009) 5163-5170. doi:10.1016/j.electacta.2009.01.037.

[30] K. Ogle, M. Serdechnova, M. Mokaddem, P. Volovitch, The cathodic dissolution of Al, Al2Cu, and Al alloys, Electrochimica Acta. 56 (2011) 1711-1718. doi:10.1016/j.electacta.2010.09.058.

[31] K. Ogle, A. Tomandl, N. Meddahi, M. Wolpers, The alkaline stability of phosphate coatings I: ICP atomic emission spectroelectrochemistry, Corros. Sci. 46 (2004) 979-995. doi:10.1016/S0010-938X(03)00182-3.

[32] K. Ogle, S. Weber, Anodic Dissolution of 304 Stainless Steel Using Atomic Emission Spectroelectrochemistry, J. Electrochem. Soc. 147 (2000) 1770-1780. doi:10.1149/1.1393433.

[33] ASTM G1-03(2011) Standard Practice for Preparing, Cleaning, and Evaluating Corrosion Test Specimens, ASTM International, 2011.

[34] C. Gabrielli, M. Keddam, H. Takenouti, V. Quang Kinh, F. Bourelier, The relationship between the impedance of corroding electrode and its polarization resistance determined by a linear voltage sweep technique, Electrochimica Acta. 24 (1979) 61-65. doi:10.1016/0013-4686(79)80042-0.

[35] S. Colin, E. Beche, R. Berjoan, H. Jolibois, A. Chambaudet, An XPS and AES study of the free corrosion of $\mathrm{Cu}-, \mathrm{Ni}-$ and Zn-based alloys in synthetic sweat, Corros. Sci. 41 (1999) 1051-1065. doi:10.1016/S0010938X(98)00141-3.

[36] M.C. Squarcialupi, G.P. Bernardini, V. Faso, A. Atrei, G. Rovida, Characterisation by XPS of the corrosion patina formed on bronze surfaces, J. Cult. Herit. 3 (2002) 199-204. doi:10.1016/S1296-2074(02)01179-2.

[37] G. Masi, C. Chiavari, J. Avila, J. Esvan, S. Raffo, M.C. Bignozzi, M.C. Asensio, L. Robbiola, C. Martini, Corrosion investigation of fire-gilded bronze involving high surface resolution spectroscopic imaging, Appl. Surf. Sci. 366 (2016) 317-327. doi:10.1016/j.apsusc.2016.01.101.

[38] C. Debiemme-Chouvy, F. Ammeloot, E.M.M. Sutter, X-ray photoemission investigation of the corrosion film formed on a polished $\mathrm{Cu}-13 \mathrm{Sn}$ alloy in aerated $\mathrm{NaCl}$ solution, Appl. Surf. Sci. 174 (2001) 55-61. doi:10.1016/S0169-4332(01)00023-X.

[39] R. Walker, Aqueous Corrosion of Tin-Bronze and Inhibition by Benzotriazole, Corrosion. 56 (2000) 12111219. doi:10.5006/1.3280509.

[40] F. Ammeloot, C. Fiaud, E.M.M. Sutter, Characterization of the oxide layers on a $\mathrm{Cu} \square 13 \mathrm{Sn}$ alloy in a $\mathrm{NaCl}$ aqueous solution without and with $0.1 \mathrm{M}$ benzotriazole. Electrochemical and photoelectrochemical contributions, Electrochimica Acta. 44 (1999) 2549-2558. doi:10.1016/S0013-4686(98)00391-0.

[41] V. Hayez, V. Costa, J. Guillaume, H. Terryn, A. Hubin, Micro Raman spectroscopy used for the study of corrosion products on copper alloys: study of the chemical composition of artificial patinas used for restoration purposes, Analyst. 130 (2005) 550-556. doi:10.1039/b419080g.

[42] F. Ospitali, C. Chiavari, C. Martini, E. Bernardi, F. Passarini, L. Robbiola, The characterization of Sn-based corrosion products in ancient bronzes: a Raman approach, J. Raman Spectrosc. 43 (2012) 1596-1603. doi:10.1002/jrs.4037.

[43] C. Alonso, E. Casero, E. Román, S.F.P. Campos, M.F.L. de Mele, Effective inhibition of the early copper ion burst release by purine adsorption in simulated uterine fluids, Electrochimica Acta. 189 (2016) 54-63. doi:10.1016/j.electacta.2015.12.093.

[44] C. Chiavari, E. Bernardi, A. Balbo, C. Monticelli, S. Raffo, M.C. Bignozzi, C. Martini, Atmospheric corrosion of fire-gilded bronze: corrosion and corrosion protection during accelerated ageing tests, Corros. Sci. 100 (2015) 435-447. doi:10.1016/j.corsci.2015.08.013. 
[45] L. Robbiola, T.T.M. Tran, P. Dubot, O. Majerus, K. Rahmouni, Characterisation of anodic layers on Cu-10Sn bronze (RDE) in aerated $\mathrm{NaCl}$ solution, Corros. Sci. 50 (2008) 2205-2215. doi:10.1016/j.corsci.2008.06.003.

[46] E. McCafferty, Graph Theory and the Passivity of Binary Alloys: More Examples, J. Electrochem. Soc. 151 (2004) B82-B89. doi:10.1149/1.1637899.

[47] R. Parsons, Handbook of electrochemical constants, Academic Press, New York, 1959.

[48] B. Malki, S. Saedlou, I. Guillotte, B. Baroux, Ab Initio Monte Carlo Simulations of the Acidic Dissolution of Stainless Steels: Influence of the Alloying Elements, J. Electrochem. Soc. 163 (2016) C807-C814. doi:10.1149/2.0151614jes.

[49] J.G. Speight, Lange's Handbook of Chemistry: Bond Dissociation Energies, n.d.

[50] P. Marcus, On some fundamental factors in the effect of alloying elements on passivation of alloys, Corros. Sci. 36 (1994) 2155-2158. doi:10.1016/0010-938X(94)90013-2. 


\section{Tables}

Table 1. Commercial copper, tin and copper-tin alloy compositions (wt\%). Commercial alloy composition testing performed via ICP analysis according to ASTM E478 [26].

\begin{tabular}{lllllllll}
\hline Alloy & UNS\# & Cu & Sn & Zn & P & Fe & Pb & Other \\
\hline $\mathrm{Cu}$ & C11000 & 99.915 & 0.001 & 0.005 & -- & 0.003 & 0.002 & -- \\
$\mathrm{Cu}-4.5 \mathrm{Sn}-0.1 \mathrm{Zn}$ & $\mathrm{C} 51000$ & 95.06 & 4.52 & 0.08 & 0.207 & 0.02 & 0.05 & $0.02 \mathrm{Si}$ \\
$\mathrm{Cu}-9.7 \mathrm{Sn}-0.1 \mathrm{Zn}$ & $\mathrm{C} 52480$ & 89.63 & 9.72 & 0.10 & 0.170 & 0.16 & 0.02 & $0.10 \mathrm{Si}$, \\
& & & & & & & & $0.05 \mathrm{Ni}$ \\
$\mathrm{Cu}-10 \mathrm{Sn}$ & -- & 99.00 & 10.00 & -- & -- & -- & -- & -- \\
$\mathrm{Sn}$ & -- & 0.06 & 99.85 & 0.001 & - & 0.004 & 0.03 & -- \\
\hline
\end{tabular}

Table 2. Artificial perspiration solution composition. Based on [11].

\begin{tabular}{lll}
\hline Chemical Name & g/L & Molarity (mM) \\
\hline $\mathrm{NaCl}-$ Sodium Chloride & 5.00 & 85.6 \\
$\mathrm{CH}_{4} \mathrm{~N}_{2} \mathrm{O}$ - Urea & 1.00 & 16.7 \\
$\mathrm{C}_{3} \mathrm{H}_{6} \mathrm{O}_{3}-\mathrm{L}(+)$ Lactic Acid $(90 \%)$ & 1.00 & 11.1 \\
$\mathrm{NH}_{4} \mathrm{OH}-$ Ammonium Hydroxide & pH Adjuster & $\sim 11$ \\
\hline
\end{tabular}

Table 3. Identified corrosion products on $\mathrm{Cu}$ and commercial $\mathrm{Cu}$-Sn alloys exposed to artificial perspiration solution up to $130 \mathrm{~h}$ at open circuit. Italicized values are obtained from literature $[36,38-40,45]$.

\begin{tabular}{ccccc}
\hline Alloy & XPS $[36,38-40,45]$ & GIXRD & $\begin{array}{c}\text { Raman } \\
\text { Spectroscopy }\end{array}$ & $\begin{array}{c}\text { Coulometric } \\
\text { Reduction Potential } \\
\text { Wave }\end{array}$ \\
\hline $\mathrm{Cu}$ & $\mathrm{Cu}_{2} \mathrm{O}$ & $\mathrm{Cu}_{2} \mathrm{O}$ & $\mathrm{Cu}_{2} \mathrm{O}$ & $\mathrm{Cu}_{2} \mathrm{O}$ \\
$\mathrm{Cu}-4.5 \mathrm{Sn}-0.1 \mathrm{Zn}$ & $\mathrm{Cu}_{2} \mathrm{O}, \mathrm{SnO}_{\mathrm{x}}$ & $\mathrm{Cu}_{2} \mathrm{O}, \mathrm{CuCl}$ & $\mathrm{Cu}_{2} \mathrm{O}$ & $\mathrm{Cu}_{2} \mathrm{O}, \mathrm{CuCl}$ \\
$\mathrm{Cu}-9.7 \mathrm{Sn}-0.1 \mathrm{Zn}$ & $\mathrm{CuCl}, \mathrm{Cu}_{2} \mathrm{O}, \mathrm{SnO}_{2}$ & $\mathrm{Cu}_{2} \mathrm{O}$ & $\mathrm{Cu}_{2} \mathrm{O}$ & $\mathrm{Cu}_{2} \mathrm{O}$ \\
$\mathrm{Sn}$ & $\mathrm{SnO}_{2}$ & -- & $\mathrm{SnO}_{\mathrm{x}}$ & $\mathrm{SnO}_{\mathrm{x}}$ \\
\hline
\end{tabular}


Table 4. XPS binding energies (eV), X-ray generated Auger electron energy $(\mathrm{eV})$, and corrosion product assignment from fit of high-resolution photoelectron spectral data on $\mathrm{Cu}-4.5 \mathrm{Sn}-0.1 \mathrm{Zn}$ after 24 hours in artificial perspiration solution at open circuit. Literature values from: [13,35-40].

\begin{tabular}{|c|c|c|c|c|}
\hline Chemical State & Orbital/Auger & $\begin{array}{c}\text { Experiment } \\
(\mathrm{eV})\end{array}$ & Literature $(\mathrm{eV})$ & Assignment \\
\hline $\mathrm{Cu}^{0}$ & $2 p_{3 / 2}$ & Not Detected & 932.7 & $\mathrm{Cu}, \mathrm{Cu}_{2} \mathrm{O}$ \\
\hline $\mathrm{Cu}^{+}$ & $2 p_{3 / 2}$ & 932.2 & $932.0,932.5,933.0$ & $\mathrm{CuCl}, \mathrm{Cu}_{2} \mathrm{O}$ \\
\hline $\mathrm{Cu}^{2+}$ & $2 p_{3 / 2}$ & Not Detected & $935.0,934.9,935.2$ & $\mathrm{CuO}, \mathrm{Cu}(\mathrm{OH})_{2}, \mathrm{CuCl}_{2}$ \\
\hline $\mathrm{Cu}_{\text {Auger }}$ & LMM & 569.8 & 569.8 & $\mathrm{CuCl}, \mathrm{Cu}_{2} \mathrm{O}$ \\
\hline $\mathrm{Sn}^{0}$ & $3 d_{5 / 2}$ & 484.7 & $484.8,485.4$ & $\mathrm{Sn}$ \\
\hline $\mathrm{Sn}^{2+}$ & $3 d_{5 / 2}$ & 486.4 & $486.0,486.6,486.9$ & $\mathrm{SnO}$ \\
\hline $\mathrm{Sn}^{4+}$ & $3 d_{5 / 2}$ & 486.4 & $486.6,486.7,487.1$ & $\mathrm{SnO}_{2}$ \\
\hline
\end{tabular}

Table 5. Anodic charge $\left(\mathrm{Coul} / \mathrm{cm}^{2}\right)$ of individual corrosion products as evaluated by coulometric reduction (CR) following $130 \mathrm{~h}$ at open circuit in artificial perspiration. N.D. - Not detected.

\begin{tabular}{|c|c|c|c|c|c|}
\hline Alloy & $\mathrm{CuCl}$ & $\begin{array}{c}\mathbf{C u}_{2} \mathbf{O} \\
\text { Coulomb }\end{array}$ & $\underset{n^{-2}}{\mathrm{SnO}_{2}}$ & $\mathrm{Cu}^{+}$ & Total \\
\hline $\mathrm{Cu}$ & N.D. & 0.120 & -- & 0.742 & 0.86 \\
\hline $\mathrm{Cu}-4.5 \mathrm{Sn}-0.1 \mathrm{Zn}$ & 0.613 & 0.772 & 0.790 & 1.337 & 3.51 \\
\hline $\mathrm{Cu}-9.7 \mathrm{Sn}-0.1 \mathrm{Zn}$ & 0.001 & 0.162 & 0.228 & 1.154 & 1.54 \\
\hline $\mathrm{Sn}$ & -- & -- & 0.014 & -- & 0.01 \\
\hline
\end{tabular}




\section{Figures}

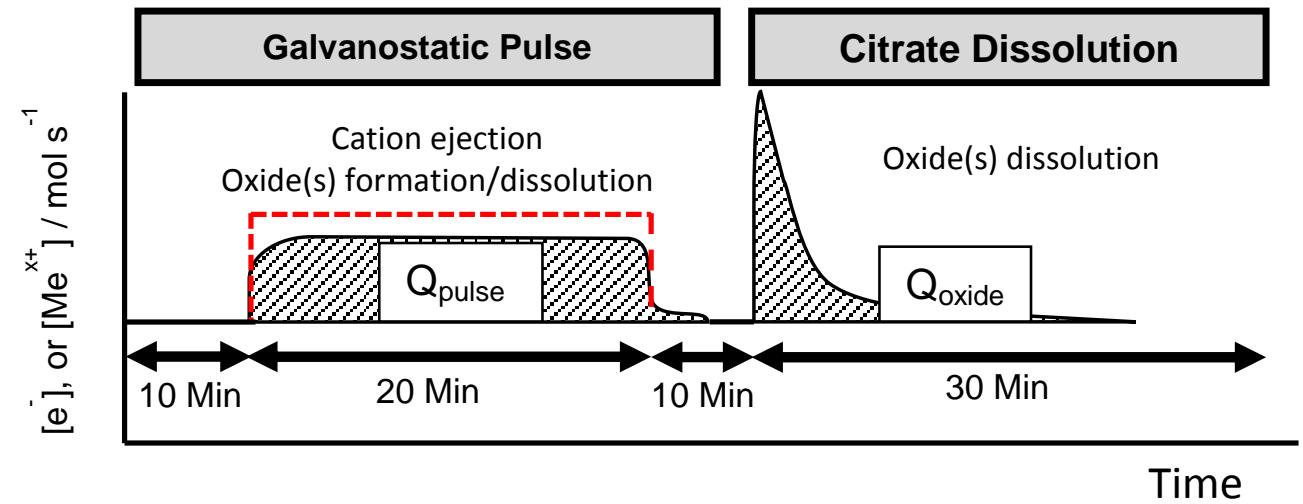

Figure 1. Schematic diagram of operando AESEC experimental method. Galvanostatic pulse conducting in artificial perspiration solution. Citrate dissolution stage was conducted in a deaerated citrate buffer solution (CBS, pH 5.0). Dashed red line indicates applied current [e $]$, Solid black lines indicate AESEC measured release $\left[\mathrm{Me}^{\mathrm{x}+}\right]$ expressed as nmol/s. Grey-shaded integrated areas under curves represent moles. 


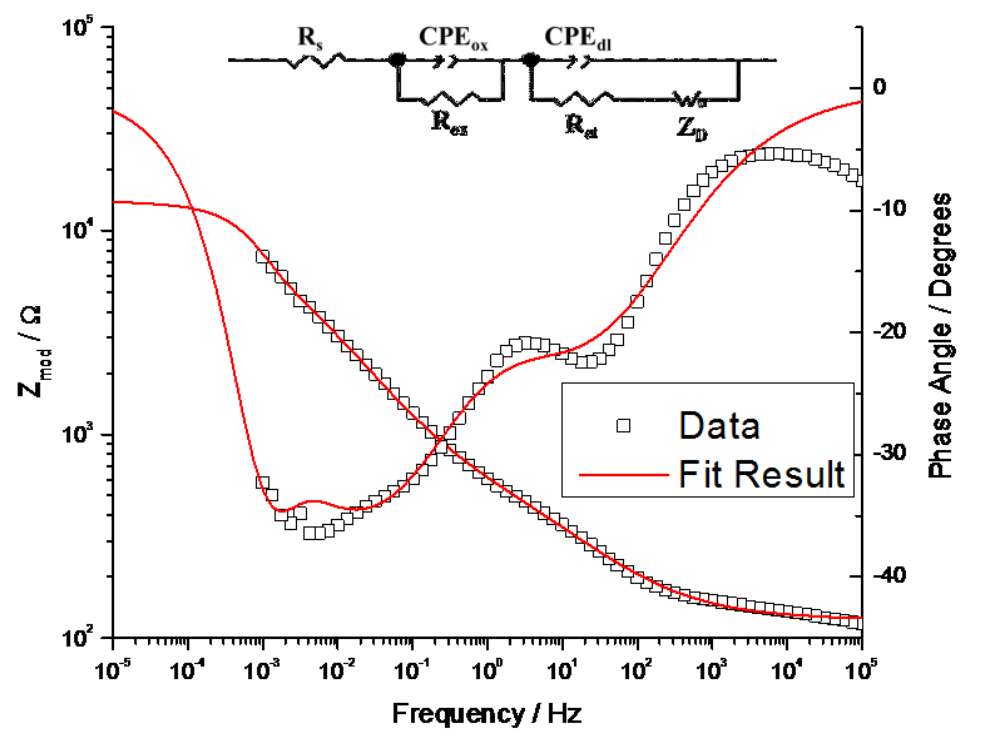

Figure 2. Equivalent DC Circuit, and representative example fit of $\mathrm{Cu}-4.5 \mathrm{Sn}-0.1 \mathrm{Zn}$ after $48 \mathrm{~h}$ in artificial perspiration solution (Area $\left.=0.8 \mathrm{~cm}^{2}\right)$. $R_{\mathrm{s}}$ - solution resistance $(122.8 \Omega), R_{\mathrm{ox}}$ - oxide resistance $(2350 \Omega), \mathrm{R}_{\mathrm{ct}}-$ charge transfer resistance $(502 \Omega), \mathrm{Z}_{\mathrm{D}}$ - diffusional Warburg impedance $\left(\mathrm{Y}_{\text {diff }}=2.12 \times 10^{-3} \mathrm{~S} \cdot \mathrm{s}^{0.5}, \mathrm{~B}=23.8 \mathrm{~s}^{0.5}\right)$, $\mathrm{CPE}_{\mathrm{ox}}$ - oxide constant phase element $\left(\mathrm{Y}_{\mathrm{ox}}=3.20 \times 10^{-3} \mathrm{~S} \cdot \mathrm{s}^{\mathrm{a}}, \mathrm{a}_{\mathrm{ox}}=0.603\right), \mathrm{CPE}_{\mathrm{dl}}-$ double layer capacitance $\left(\mathrm{Y}_{\mathrm{dl}}=\right.$ $\left.3.89 \times 10^{-4} \mathrm{~S} \cdot \mathrm{s}^{\mathrm{a}}, \mathrm{a}_{\mathrm{dl}}=0.5\right)$. 

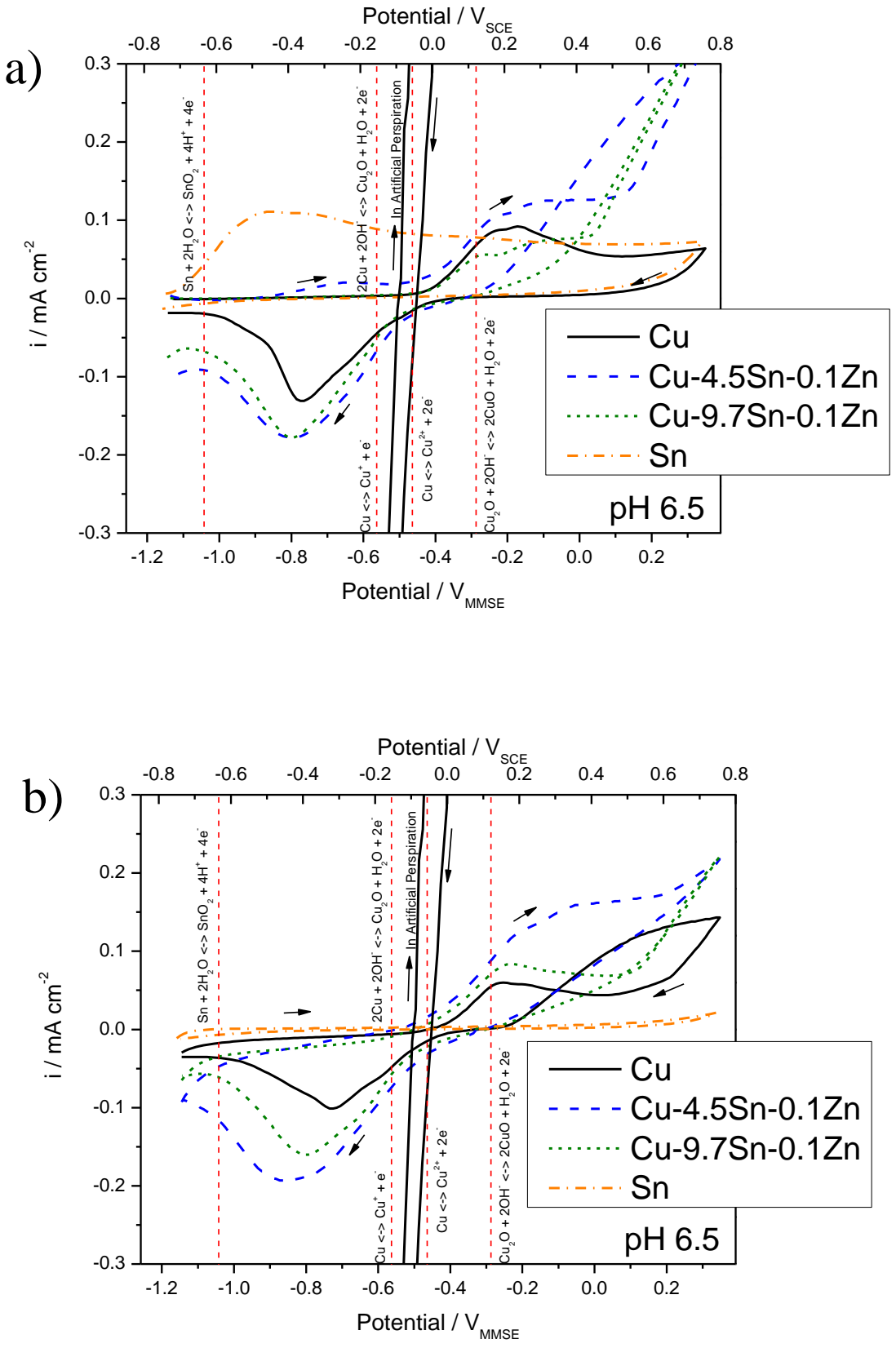

M.J. Hutchison 3 


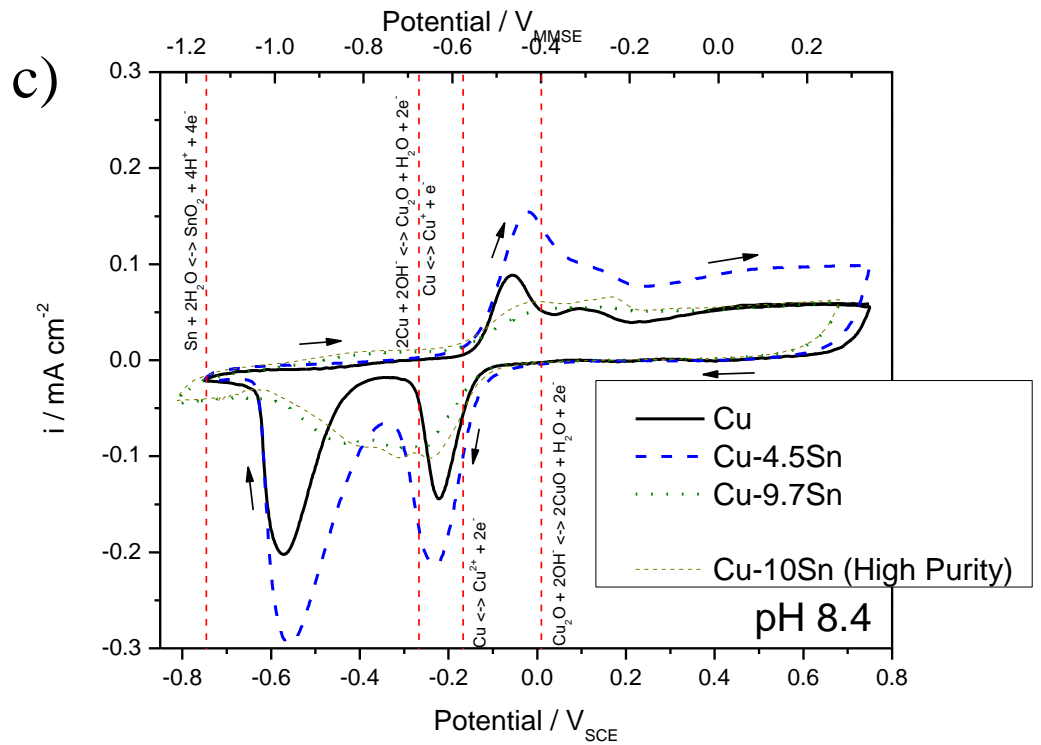

Figure 3. Cyclic voltammograms in deaerated boric acid buffer (pH 6.5) and borate buffer (pH 8.4). a) Boric acid buffer cycle 1, b) boric acid buffer cycle 3, c) borate buffer cycle 3. Scan rate $10 \mathrm{mV} / \mathrm{s}$. Samples were held at -1.4 $\mathrm{V}_{\text {MMSE }}$ for 10 min prior to initial scan. 

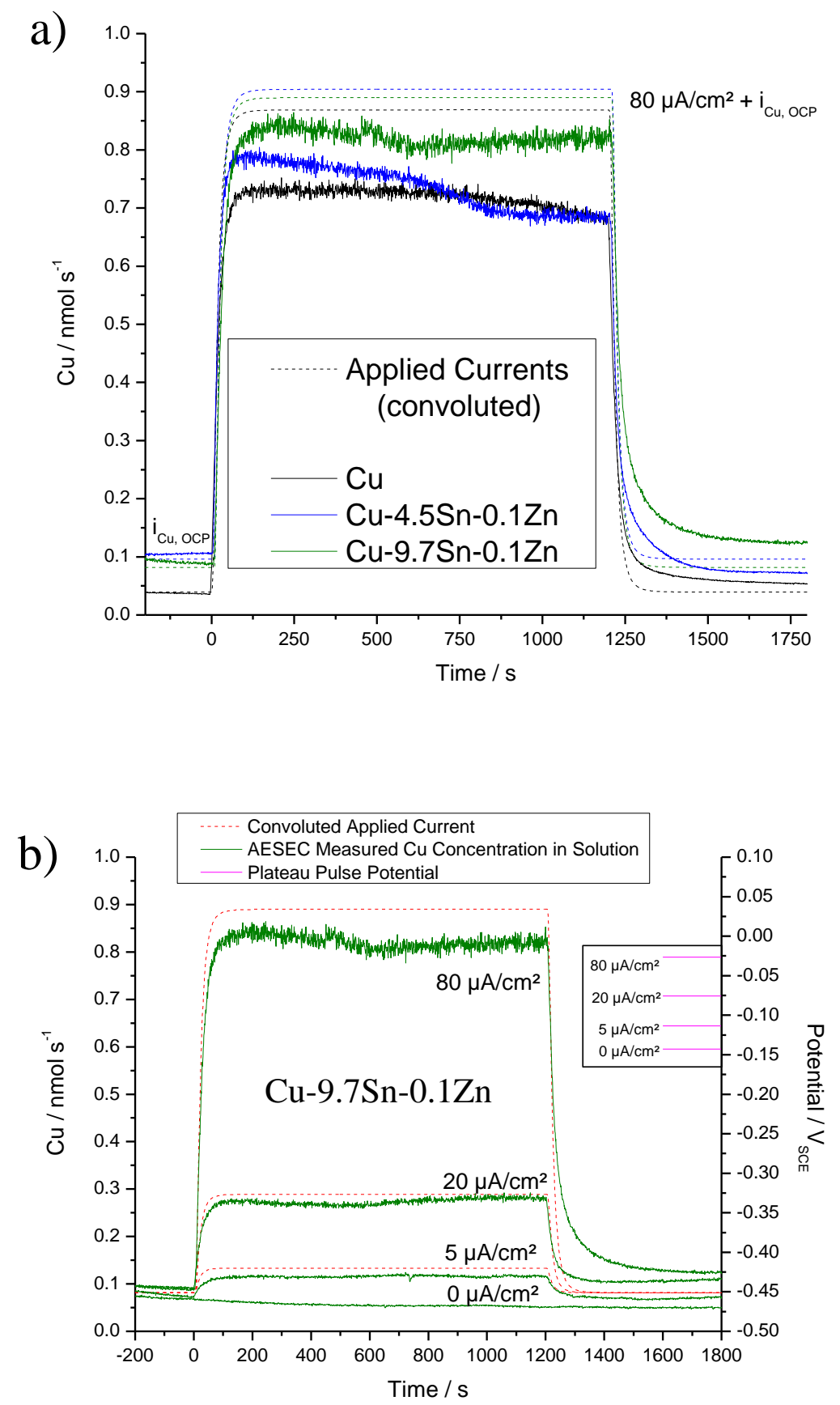

Figure 4. Operando AESEC galvanostatic pulse measurements of $\mathrm{Cu}-\mathrm{Sn}$ samples in artificial perspiration solution at an applied current of $80 \mu \mathrm{A} / \mathrm{cm}^{2}$ (a) and multiple applied currents of $0,5,20$, and $80 \mu \mathrm{A} / \mathrm{cm}^{2}$ on Cu$9.7 \mathrm{Sn}-0.1 \mathrm{Zn}(\mathrm{b})$. Exposed area $=1 \mathrm{~cm}^{2}$. Convoluted applied current profiles are shown in dashed lines. Convolution of the current was used to account for residence time of the flow condition and cell geometry [28]. Applied current convolution includes addition of non-zero open circuit corrosion rate $\left(\mathrm{i}_{\mathrm{Cu}}, \mathrm{OCP}\right)$ measured during prior 10 min OCP (Time < 0). Measured steady-state potentials in the plateau region of the pulse are overlaid with magenta lines. 


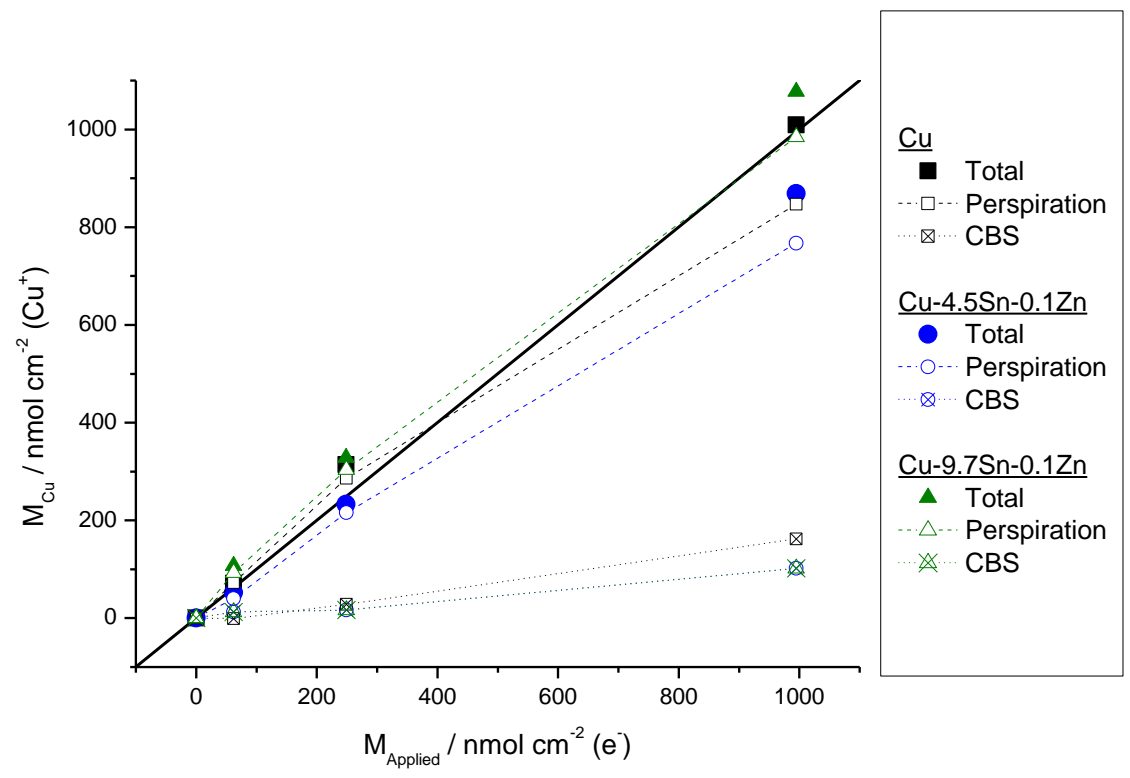

Figure 5. AESEC total amount of $\mathrm{Cu}$ from soluble release in artificial perspiration + oxide dissolution in CBS on $\mathrm{Cu}$ compared to $\mathrm{Cu}-4.5 \mathrm{Sn}-0.1 \mathrm{Zn}$. Assumed $\mathrm{Cu}^{+}$valence state for both soluble release and oxide. Line indicates 1:1 correlation between applied current and total detected ion concentration. $\mathbf{M}_{\text {Applied }}$ : Applied anodic current. $\mathrm{M}_{\mathrm{Cu}}$ : $\mathrm{Cu}$ ions detected via downstream ICP for both artificial perspiration and CBS stages. Compensated for OCP corrosion rate.

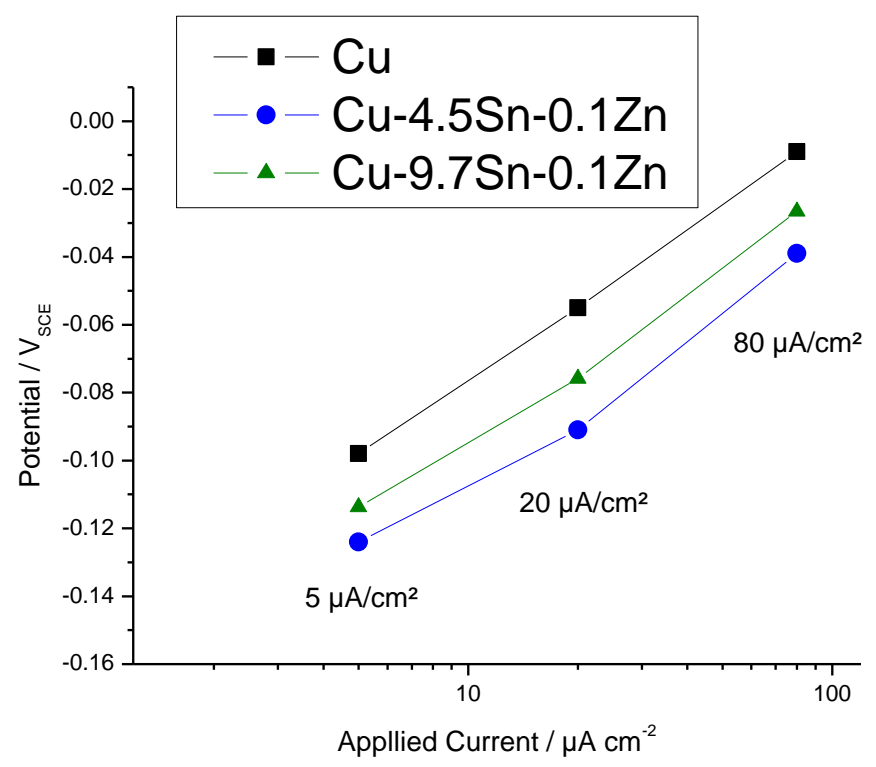

Figure 6. Measured potential plotted against applied current during anodic dissolution stage of AESEC measurements in artificial perspiration. 


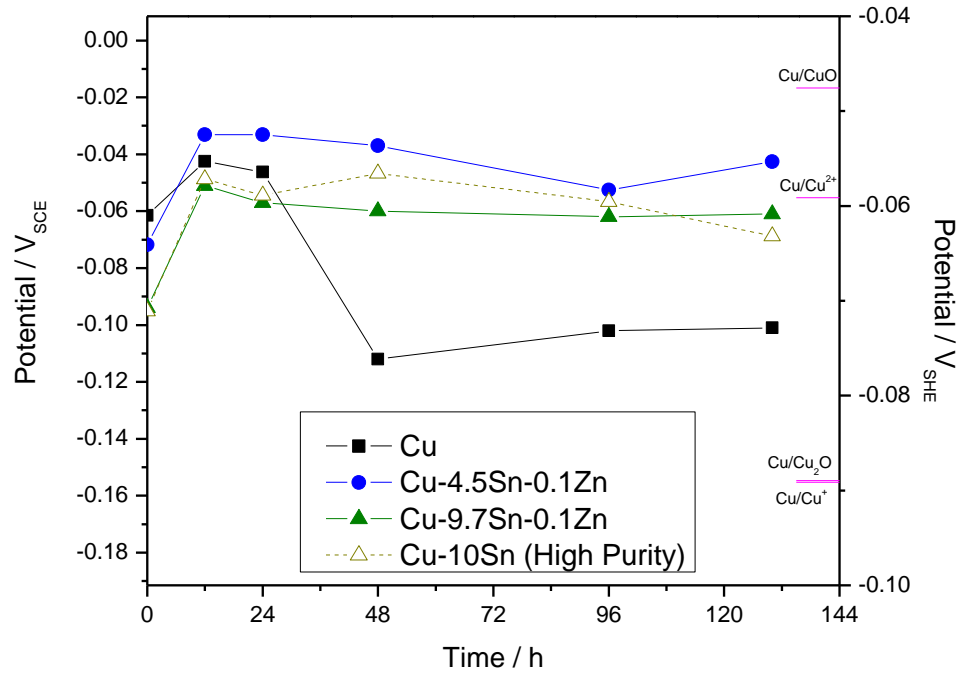

Figure 7. Open circuit potential of $\mathrm{Cu}$ compared to commercial $\mathrm{Cu}-\mathrm{Sn}$ alloys fully immersed in naturally-aerated artificial perspiration solution ( $\mathrm{pH}$ 6.5) up to 130 hours. Selected Nernst potentials for half-cell reactions of interest are overlaid on graph. $\left(\mathrm{E}_{\mathrm{r}}: \mathrm{Sn} / \mathrm{SnO}_{2} \rightarrow-0.75 \mathrm{~V}_{\mathrm{SCE}}\right.$, not shown) 


\section{Optical}

a)

b)
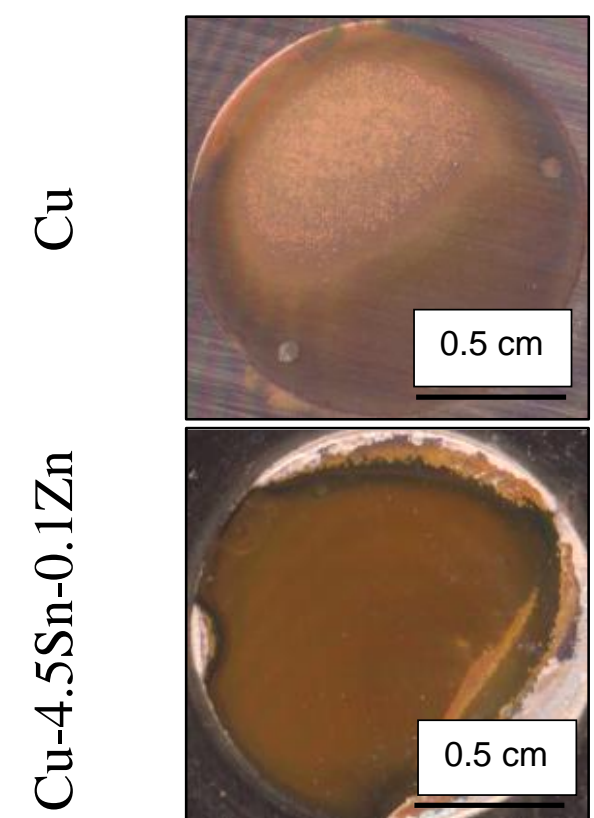

c)

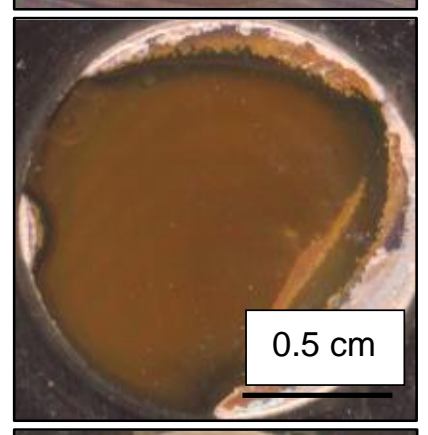

范

z

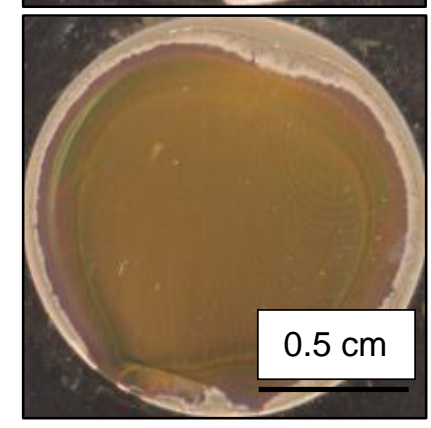

$\underline{\text { SEM Micrographs }}$
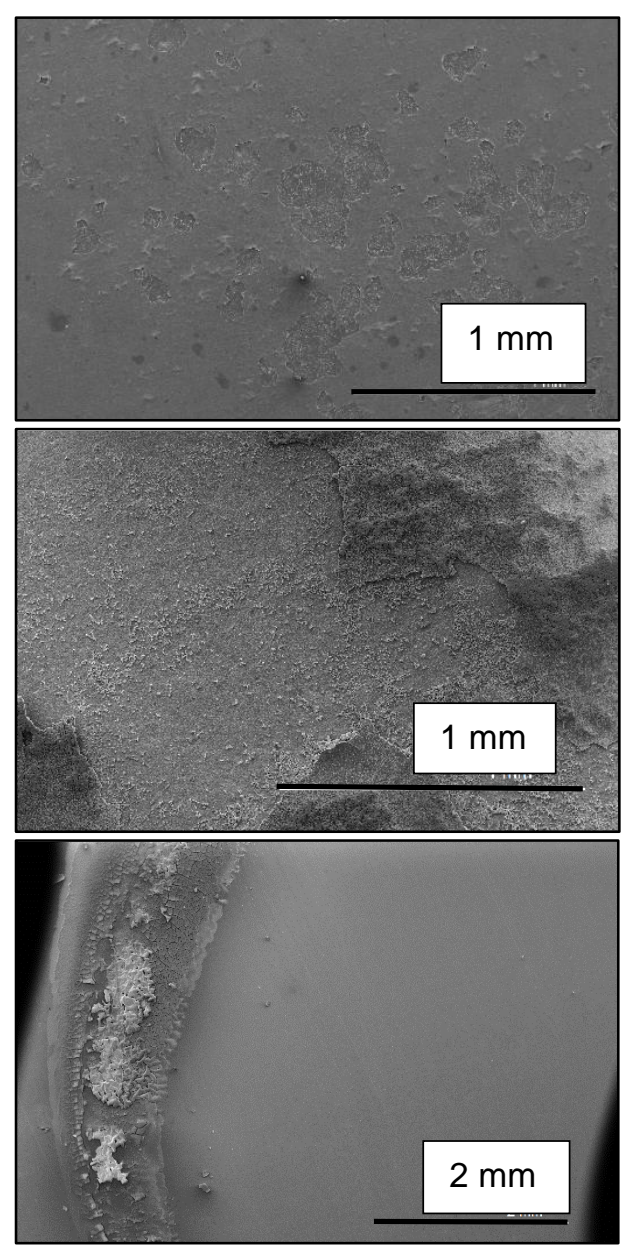

Figure 8. Visual condition and secondary electron images of $\mathrm{Cu}$ and $\mathrm{Cu}-\mathrm{Sn}$ samples post-exposure following open circuit in artificial perspiration solution after 130 hours. a) $\mathrm{Cu}$, b) $\mathrm{Cu}-4.5 \mathrm{Sn}-0.1 \mathrm{Zn}$, and c) $\mathrm{Cu}-9.7 \mathrm{Sn}-0.1 \mathrm{Zn}$.
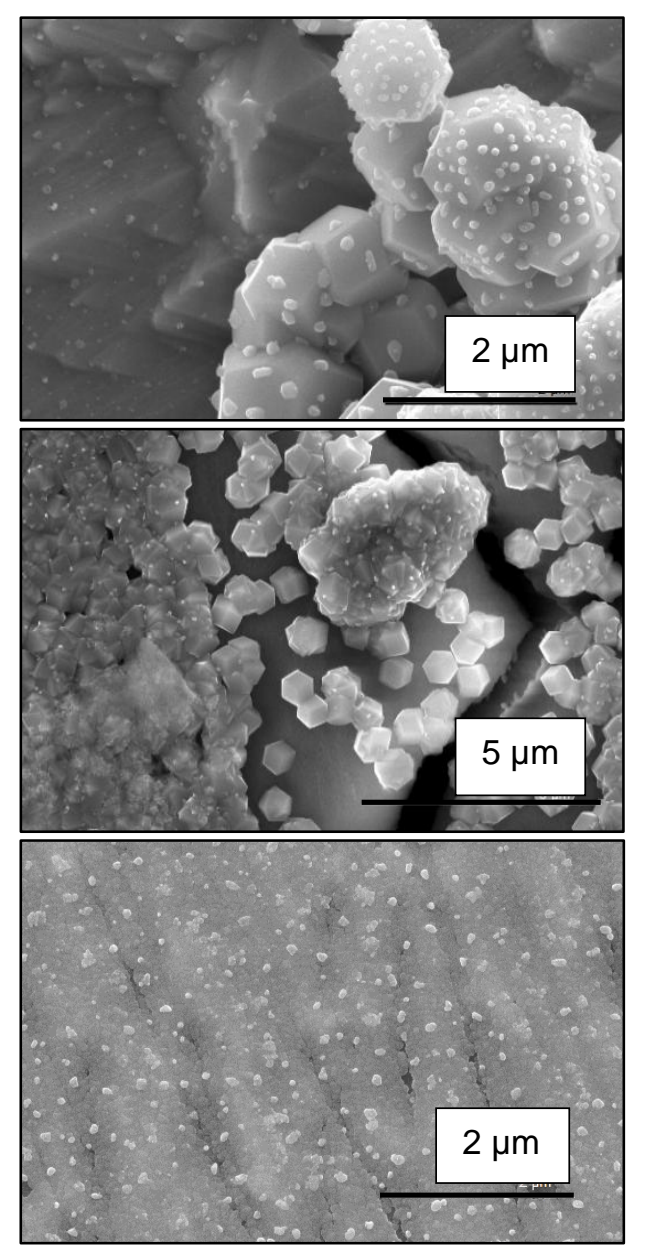

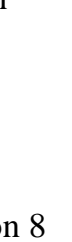



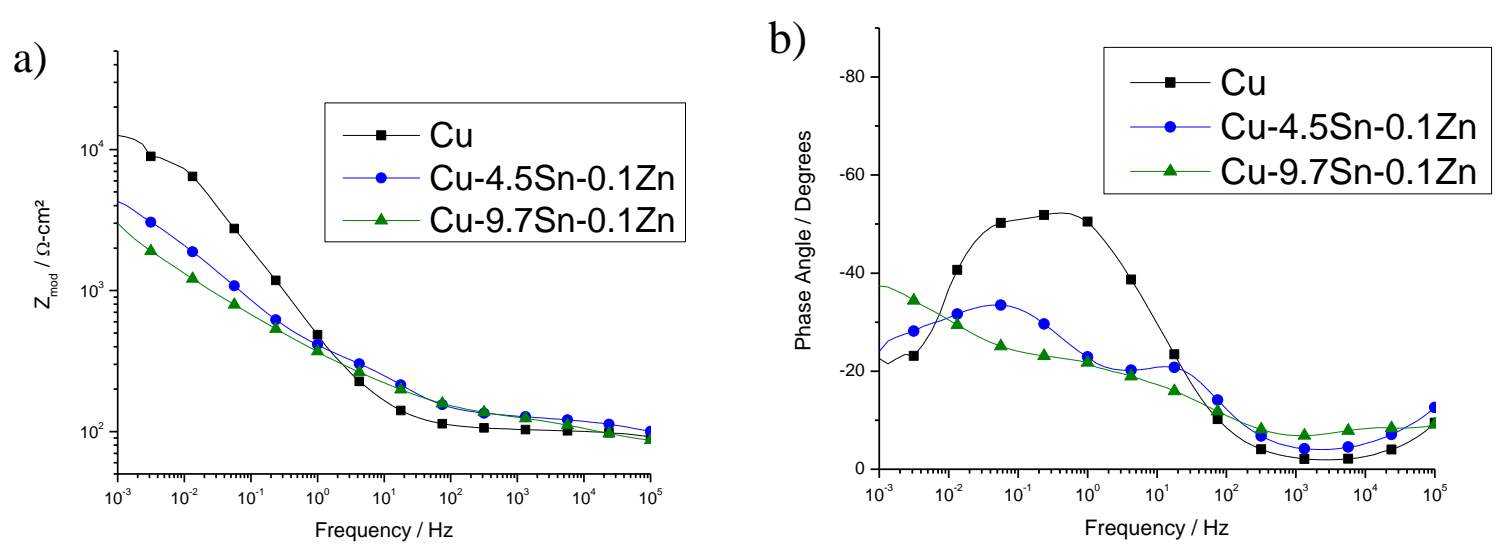

Figure 9. Comparison of electrochemical impedance behavior of $\mathrm{Cu}$ and commercial $\mathrm{Cu}-\mathrm{Sn}$ alloys in artificial perspiration solution after 130 hours at open circuit. 
a)

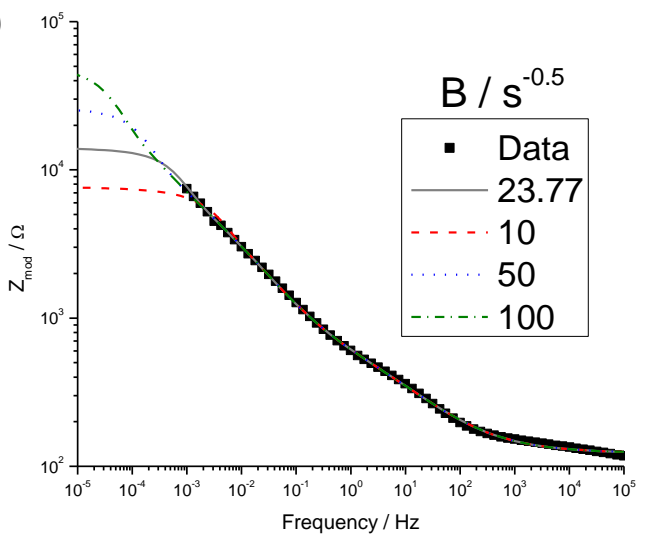

c)

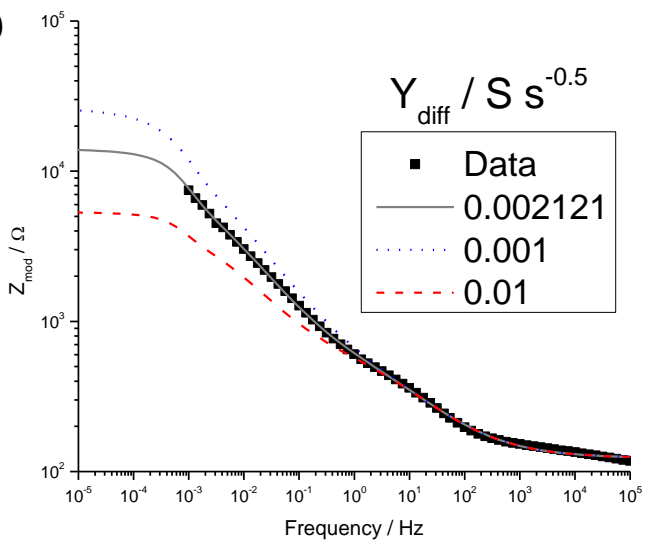

b)

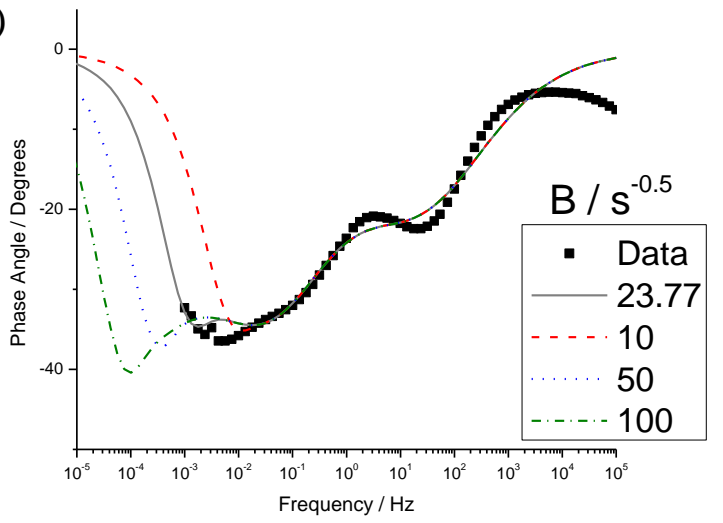

d)

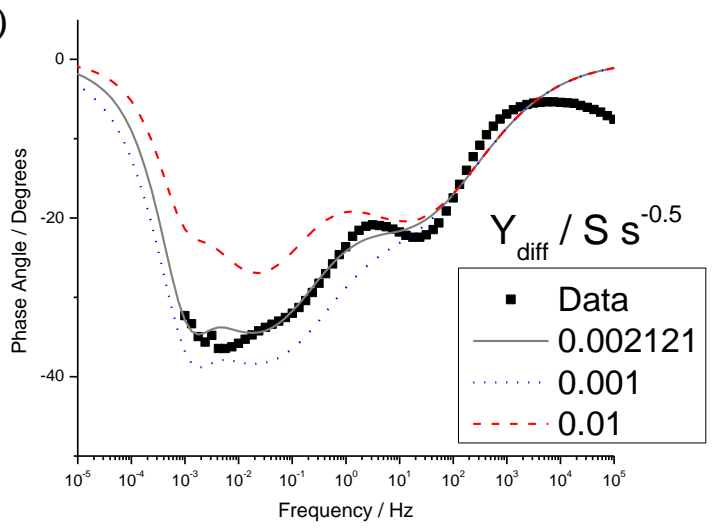

Figure 10. Equivalent circuit sensitivity study: Selected ranges for values of $B$ ( $a$ and $b$ ), and $Y_{\text {diff }}(c$ and d), about best fit (solid line) and relative effect of selected fit parameter range on the calculated impedance response of magnitude ( $a$ and $c$ ) and phase angle ( $b$ and d) for the simulated DC equivalent circuit (see Figure 2). 


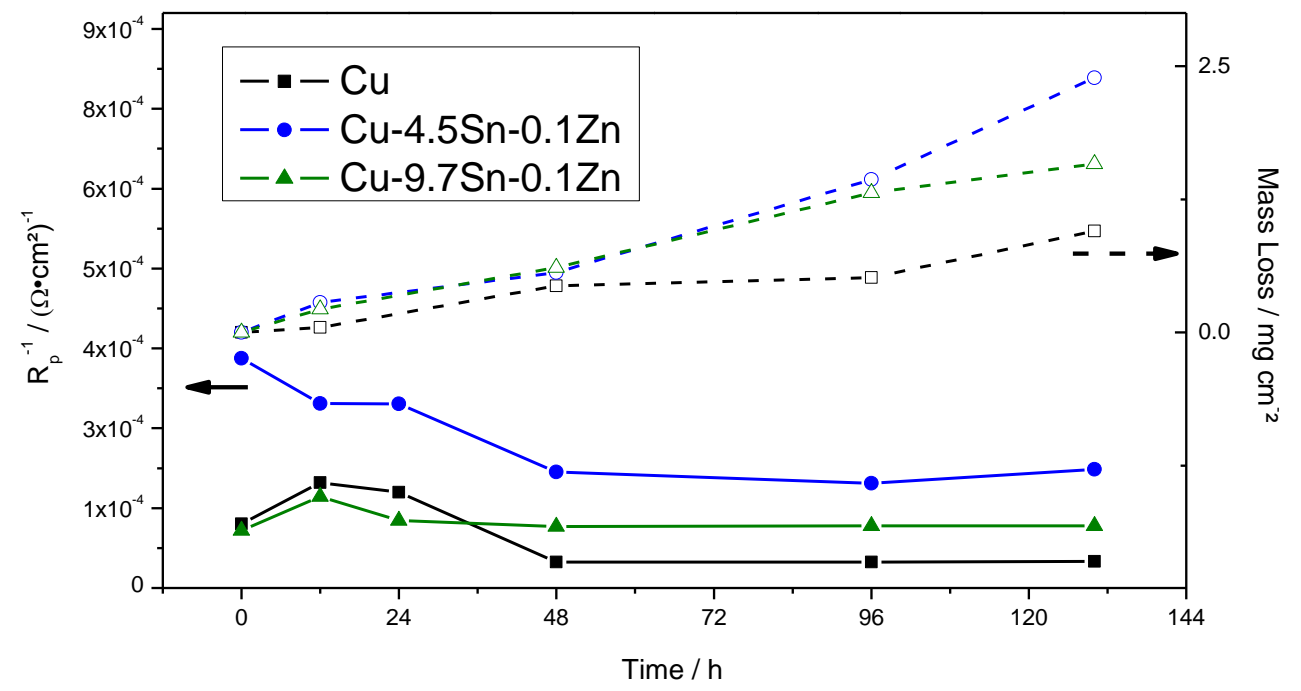

Figure 11. Inverse polarization resistance $\left(1 / R_{p}\right)$ values obtained from circuit fit of experimental impedance response data (Filled Symbols) and mass loss (Open Symbols) of $\mathrm{Cu}$ and commercial $\mathrm{Cu}-\mathrm{Sn}$ alloys corroded at open circuit in artificial perspiration solution. Corrosion product removal for mass loss facilitated by 2-3 min exposure to $6 \mathrm{M} \mathrm{HCl}$. 

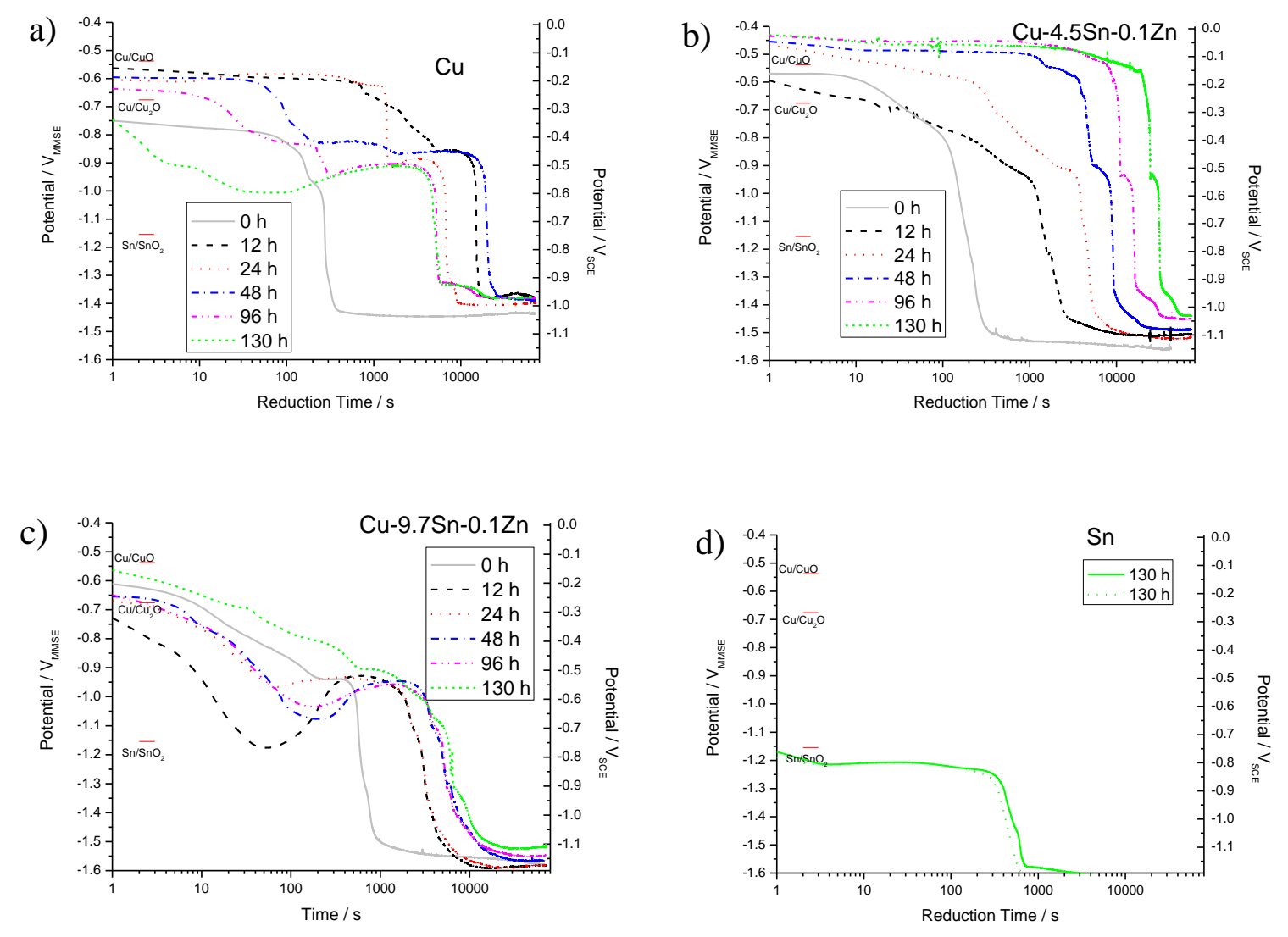

Figure 12. Coulometric cathodic reduction in deaerated borate buffer $(\mathrm{pH}$ 8.4) of commercial $\mathrm{Cu}-\mathrm{Sn}$ alloys following exposures in artificial perspiration solution at open circuit up to 130 hours. Applied cathodic current of $-20 \mu \mathrm{A}$ over electrode area $0.8 \mathrm{~cm}^{2}\left(-25 \mu \mathrm{A} / \mathrm{cm}^{2}\right)$. (a) $\mathrm{Cu}$, (b) $\mathrm{Cu}-4.5 \mathrm{Sn}-0.1 \mathrm{Zn}$, (c) $\mathrm{Cu}-9.7 \mathrm{Sn}-0.1 \mathrm{Zn}$, and (d) Sn. 


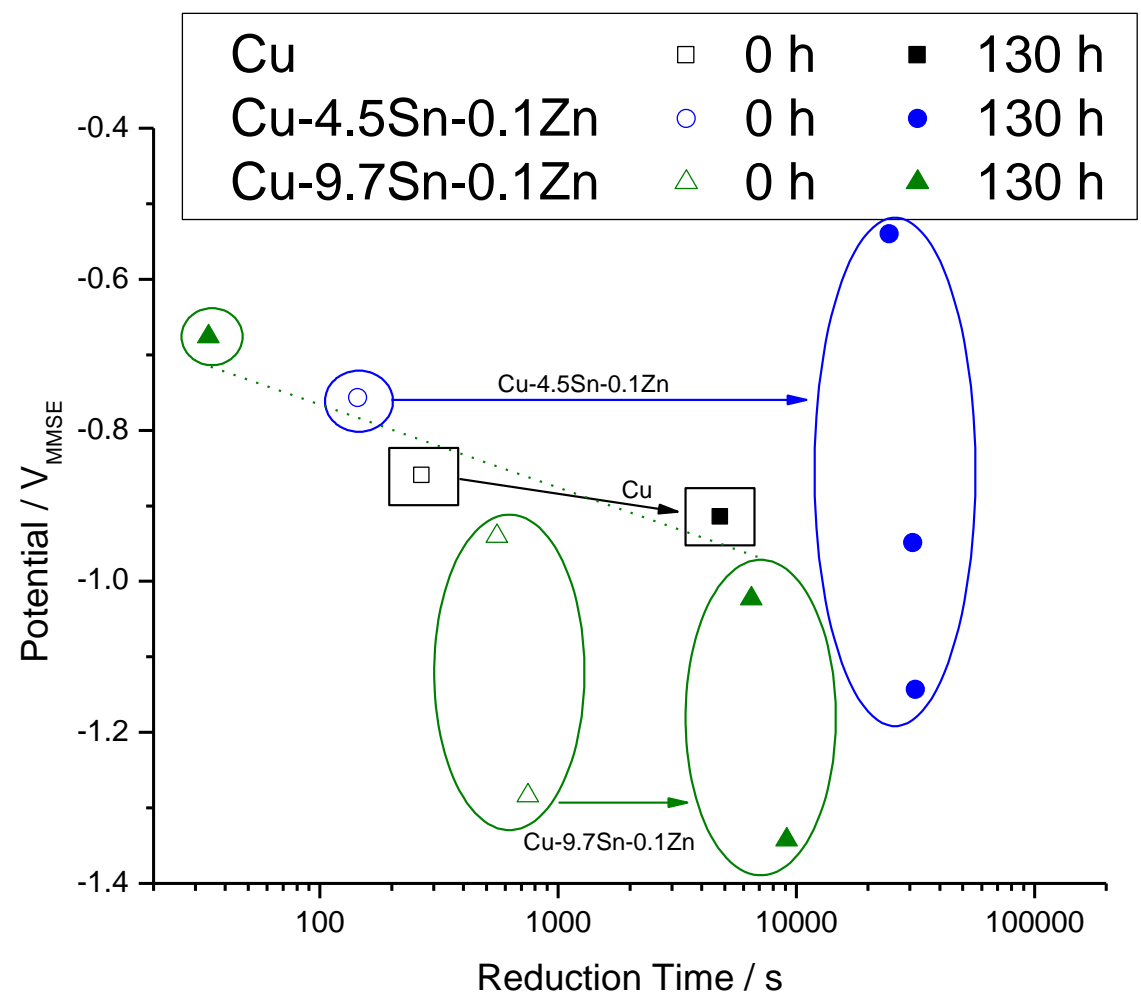

Figure 13. Corrosion product terminus reduction times and reduction plateau potentials of coulometric cathodic reduction on $\mathrm{Cu}$ and commercial $\mathrm{Cu}-\mathrm{Sn}$ alloys freshly polished (Open Symbols) and exposed for 130 hours (Filled Symbols) in artificial perspiration solution at open circuit. 


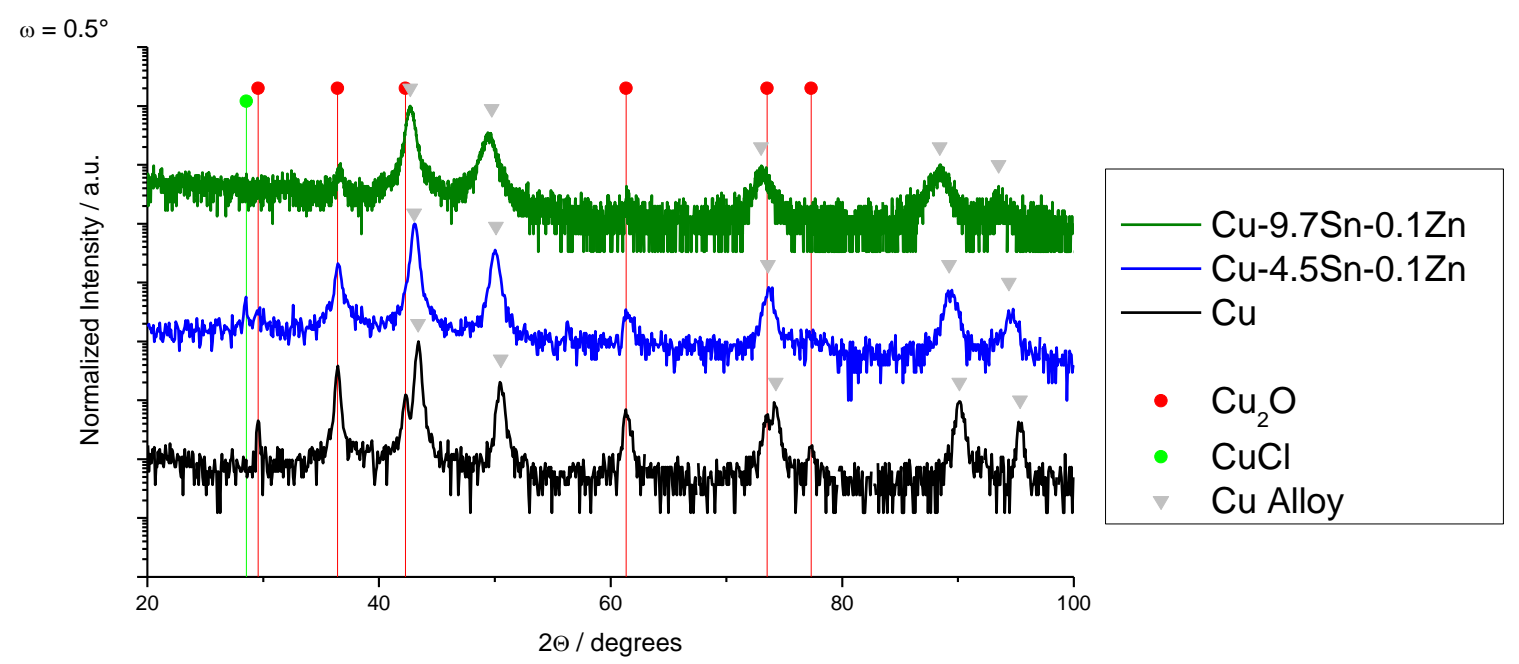

Figure 14. GIXRD of surface corrosion products on commercial $\mathrm{Cu}$-Sn alloys compared to $\mathrm{Cu}$ following $130 \mathrm{~h}$ Exposure to artificial perspiration solution at open circuit. Gray triangles represent base alloy FCC Cu peaks calculated with stretched lattice parameter fit of a substitutional solid solution alloy. Corrosion product identification was facilitated using standard X-Ray PDF cards (ICDD ${ }^{\circledR}$ PDF-4+).

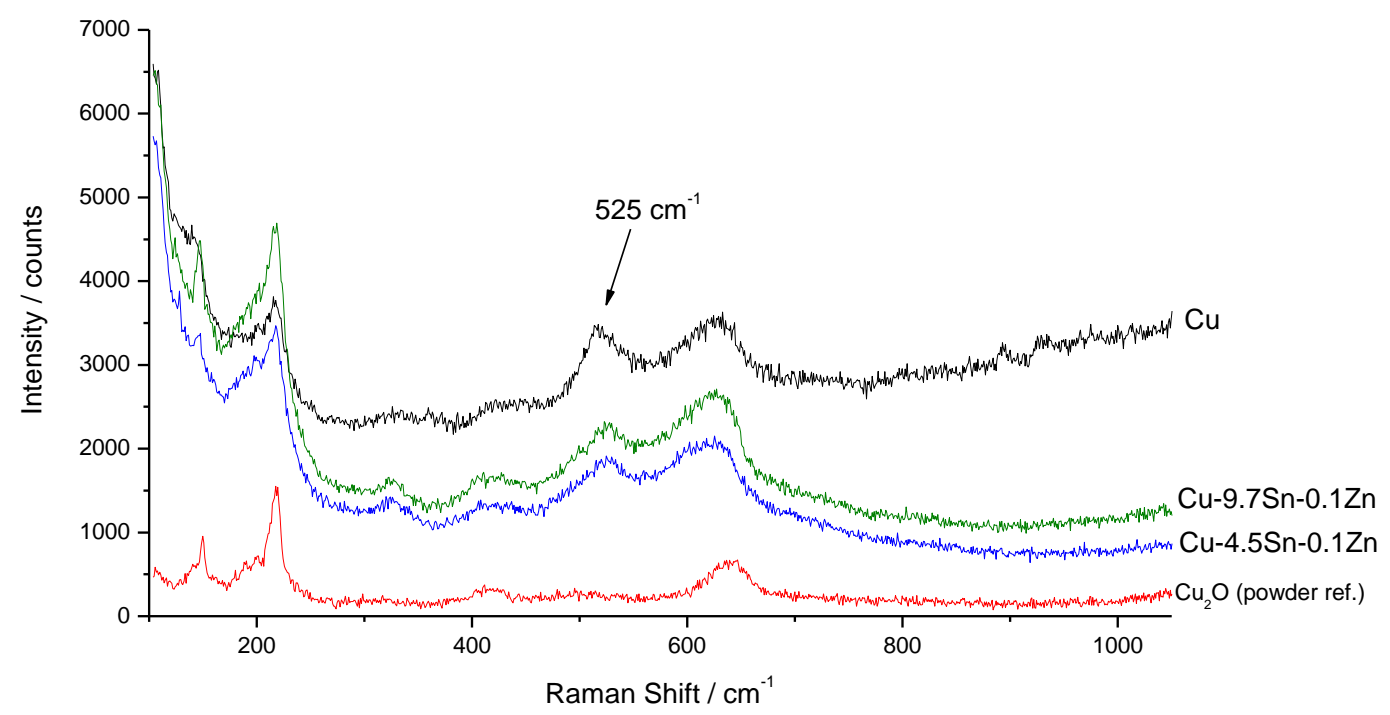

Figure 15. Ex Situ Raman spectroscopy of surface corrosion products on $\mathrm{Cu}$ and commercial $\mathrm{Cu}-\mathrm{Sn}$ alloys following $130 \mathrm{~h}$ exposure to artificial perspiration solution at open circuit. Cuprite $\left(\mathrm{Cu}_{2} \mathrm{O}\right)$ cold-pressed powder reference (red) displayed for comparison. Labeled peak at $525 \mathrm{~cm}^{-1}$ is discussed in text. 


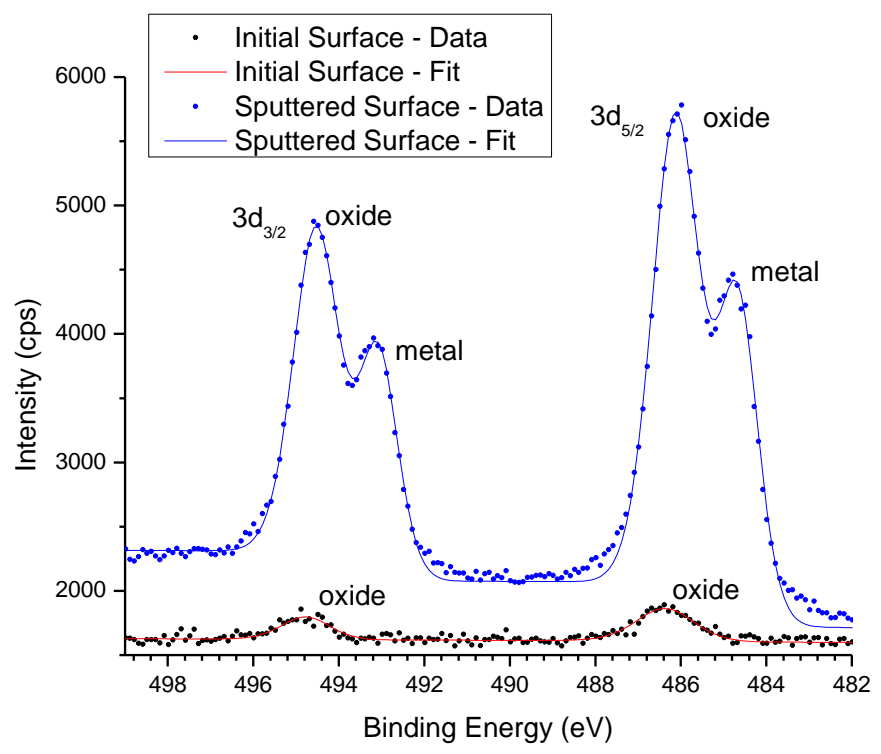

Figure 16. Initial and sputtered surface high-resolution XPS spectra of Cu-4.5Sn-0.1Zn sample exposed for 24 hours in artificial perspiration focused on $S n 3 d$ range including $3 d_{3 / 2}$ and $3 d_{5 / 2}$ regions.

a)

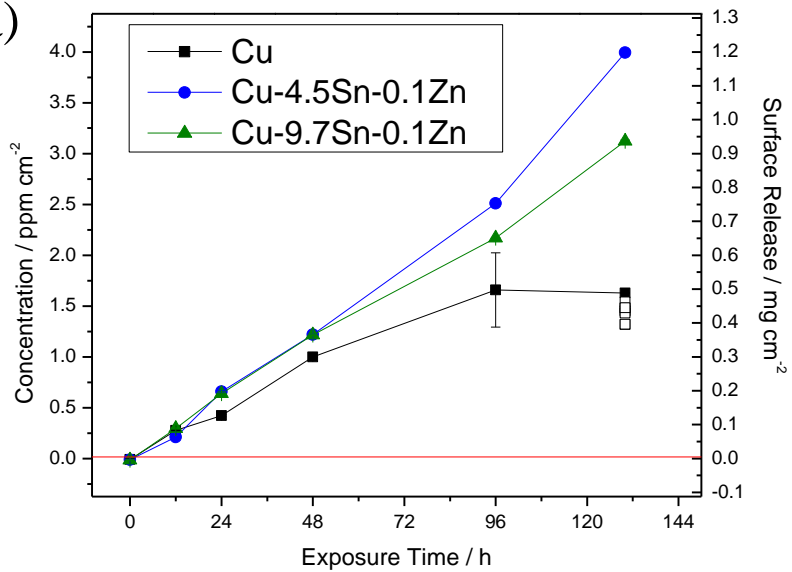

b)

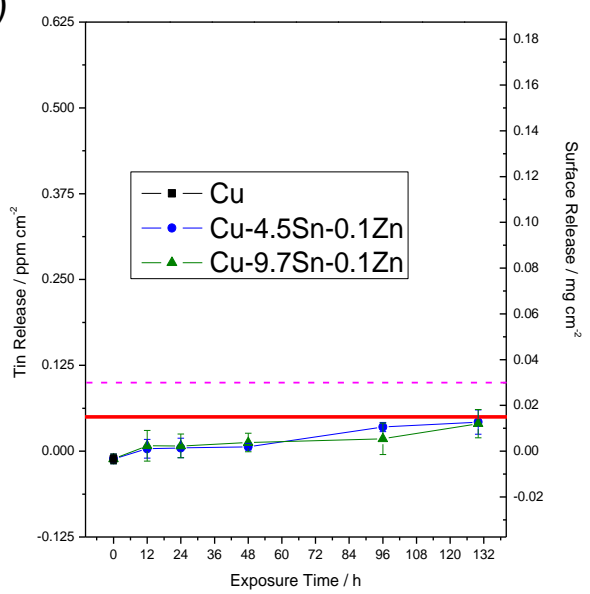

Figure 17. Copper release (a) available for antimicrobial function measured via ICP-OES (red line: Cu LOD) Open symbols are replicates. Tin release (b) was below LOD of $\sim 40 \mathrm{ppb}$ (red line). Magenta dashed line: expected soluble $\mathrm{Sn}$ assuming congruent dissolution (see text). Soluble ion concentration in artificial perspiration solution was measured from aliquots of solution taken from open circuit corrosion cells at specified time points. Exposed area $0.8 \mathrm{~cm}^{2}$, solution volume $300 \mathrm{~mL}$. 


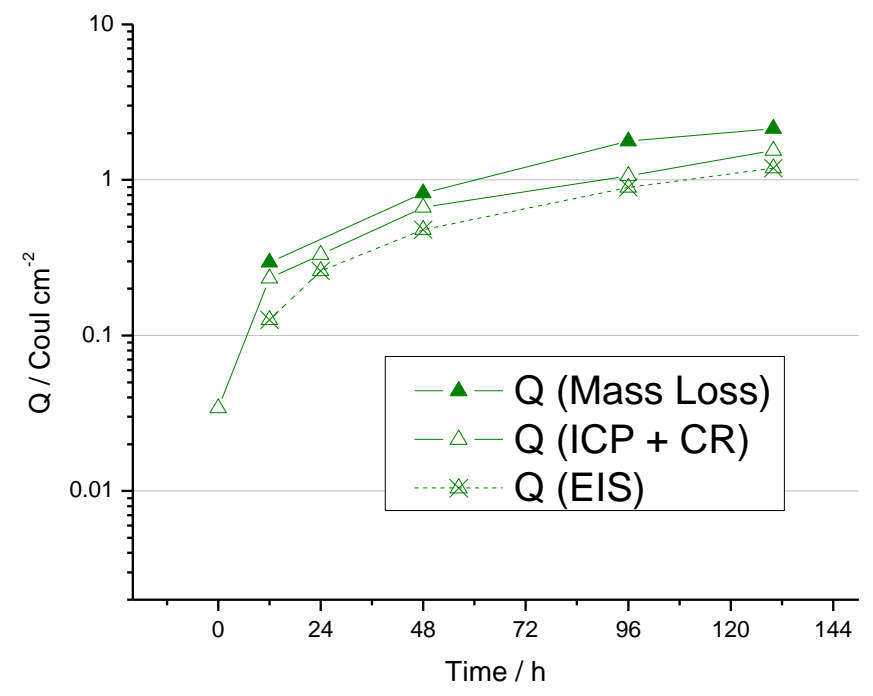

Figure 18. Example comparison of total anodic charge as a function of time for $\mathrm{Cu}-9.7 \mathrm{Sn}-0.1 \mathrm{Zn}$ alloy as measured by various techniques following open circuit exposure to artificial perspiration up to 130 hours. ICP + CR represents the anodic charge from both released ions (ICP) and corrosion products (CR). 

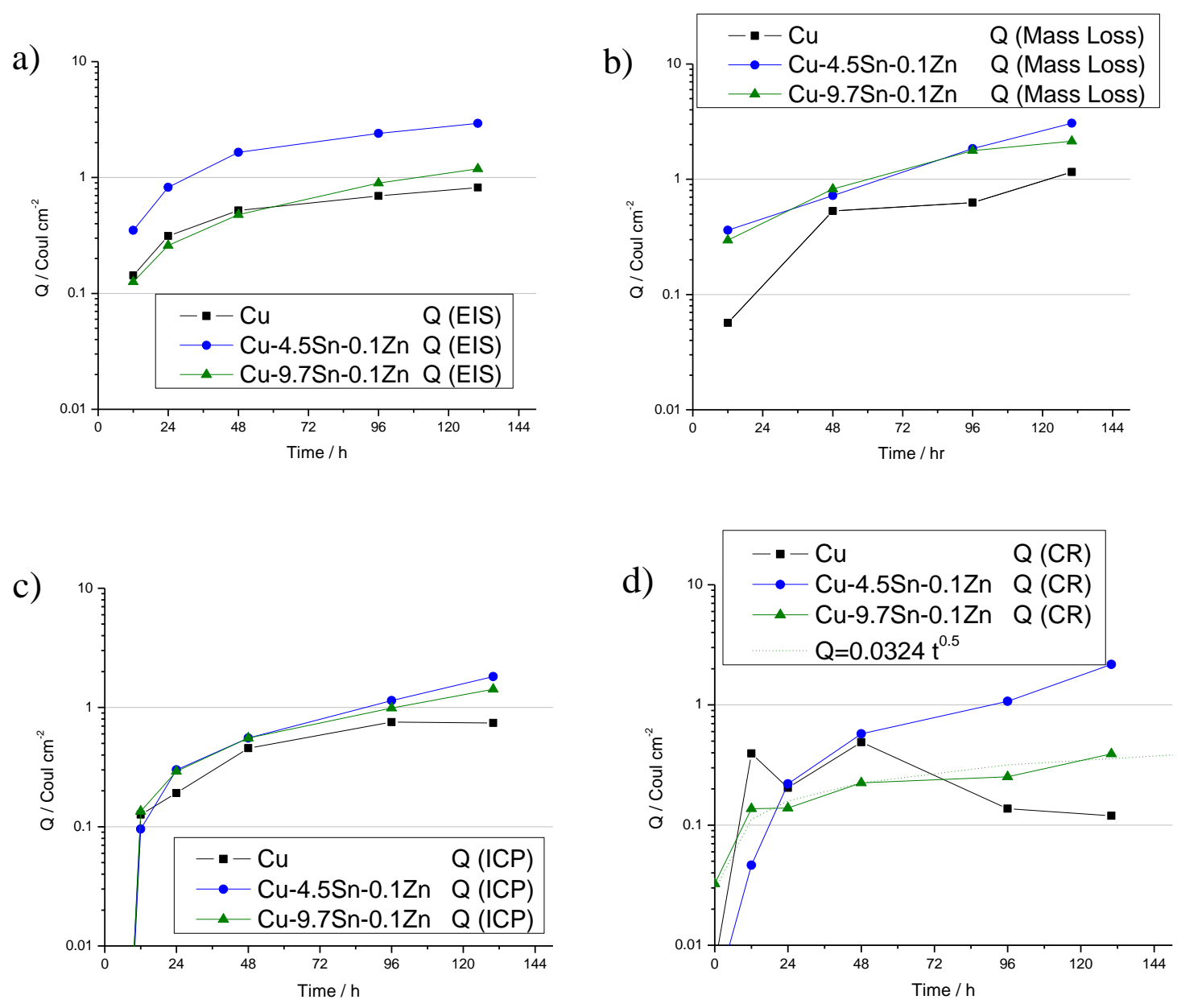

Figure 19. Comparison of anodic charge assessments by alloy composition as measured by various techniques: (a) Total anodic charge by EIS, (b) total anodic charge by mass loss, (c) released soluble Cu by ICP-OES, (d) corrosion product charge by coulometric reduction. 

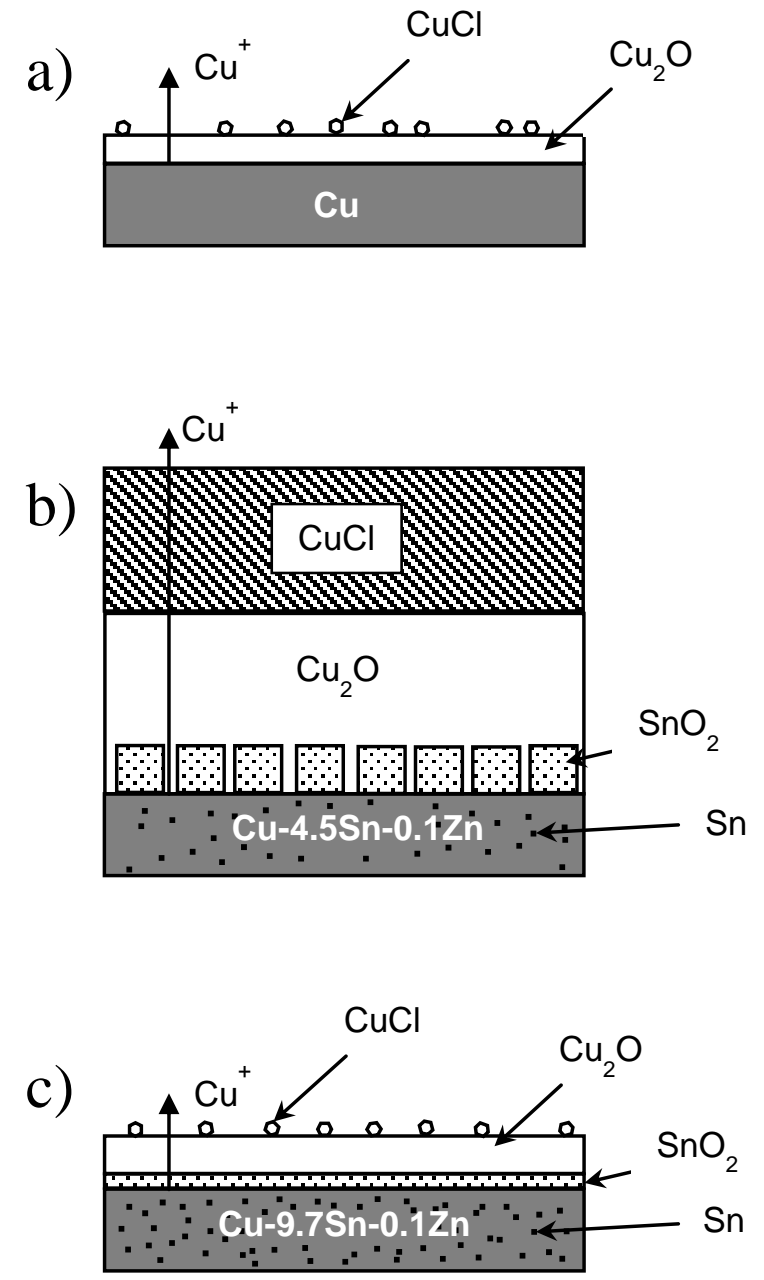

Figure 20. Schematic cross-sectional description of corrosion product morphology following open circuit exposure in artificial perspiration for a) $\mathrm{Cu}$, b) $\mathrm{Cu}-4.5 \mathrm{Sn}-0.1 \mathrm{Zn}$, and c) $\mathrm{Cu}-9.7 \mathrm{Sn}-0.1 \mathrm{Zn}$. Relative dimensions of corrosion products are based on results in Table 5. 